\title{
Assessment of Light-duty Plug-in Electric Vehicles in the United States, 2010 - 2019
}

Energy Systems Division 


\begin{abstract}
About Argonne National Laboratory
Argonne is a U.S. Department of Energy laboratory managed by UChicago Argonne, LLC under contract DE-AC02-06CH11357. The Laboratory's main facility is outside Chicago, at 9700 South Cass Avenue, Lemont, Illinois 60439. For information about Argonne and its pioneering science and technology programs, see www.anl.gov.
\end{abstract}

\title{
DOCUMENT AVAILABILITY
}

Online Access: U.S. Department of Energy (DOE) reports produced after 1991 and a growing number of pre-1991 documents are available free at OSTI.GOV (http://www.osti.gov/),

a service of the US Dept. of Energy's Office of Scientific and Technical Information.

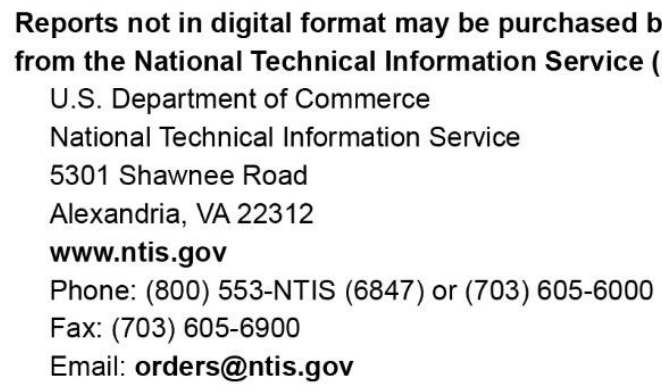

Reports not in digital format are available to DOE and DOE contractors from the Office of Scientific and Technical Information (OSTI):

U.S. Department of Energy

Office of Scientific and Technical Information

P.O. Box 62

Oak Ridge, TN 37831-0062

www.osti.gov

Phone: (865) 576-8401

Fax: (865) 576-5728

Email: reports@osti.gov

\footnotetext{
Disclaimer

This report was prepared as an account of work sponsored by an agency of the United States Government. Neither the United States Government nor any agency thereof, nor UChicago Argonne, LLC, nor any of their employees or officers, makes any warranty, express or implied, or assumes any legal liability or responsibility for the accuracy, completeness, or usefulness of any information, apparatus,

product, or process disclosed, or represents that its use would not infringe privately owned rights. Reference herein to any specific commercial product, process, or service by trade name, trademark, manufacturer, or otherwise, does not necessarily constitute or imply its endorsement, recommendation, or favoring by the United States Government or any agency thereof. The views and opinions of document authors expressed herein do not necessarily state or reflect those of the United States Government or any agency thereof, Argonne National Laboratory, or UChicago Argonne, LLC.
} 


\section{Assessment of Light-duty Plug-in Electric Vehicles in the United States, $2010-2019$}

by

David Gohlke and Yan Zhou

Energy Systems Division, Argonne National Laboratory

June 2020 
4 


\section{CONTENTS}

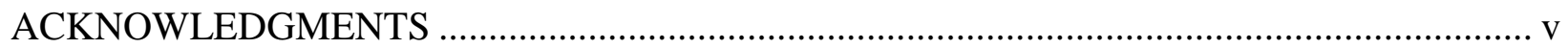

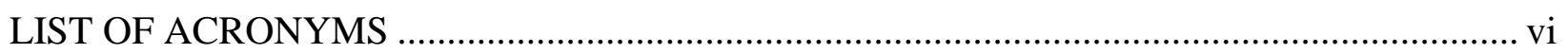

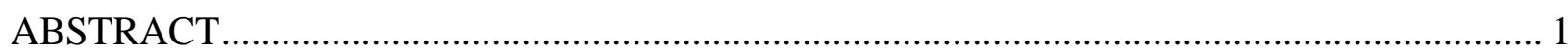

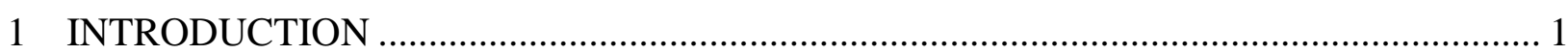

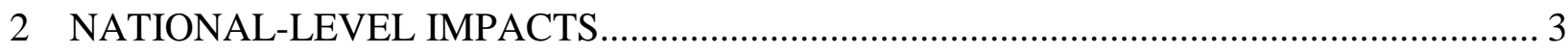

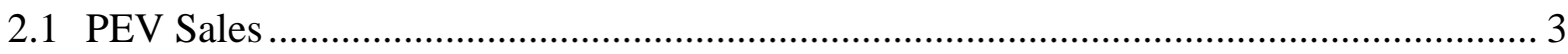

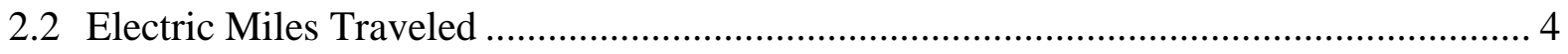

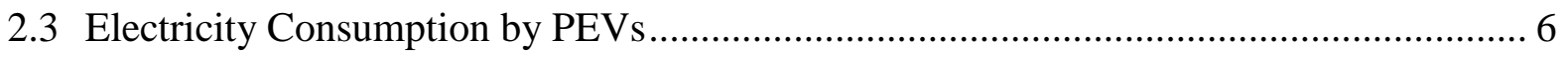

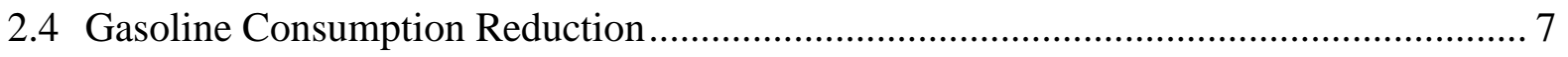

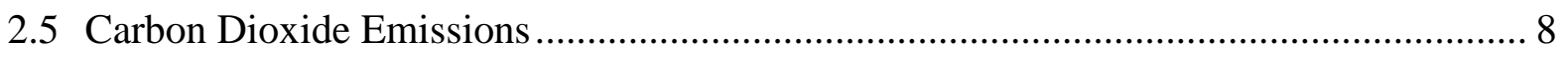

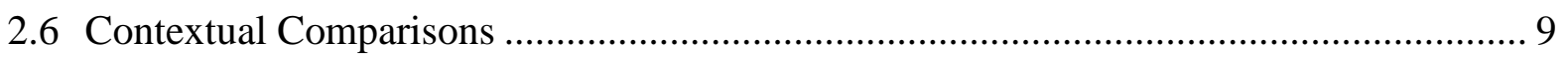

3 VEHICLE CHARACTERISTICS ....................................................................... 10

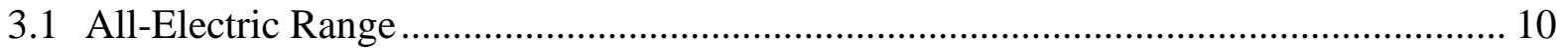

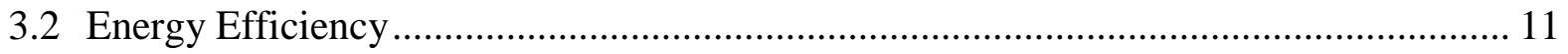

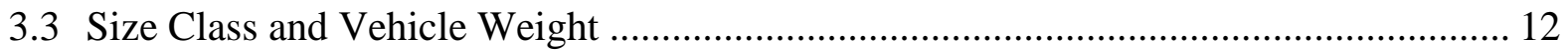

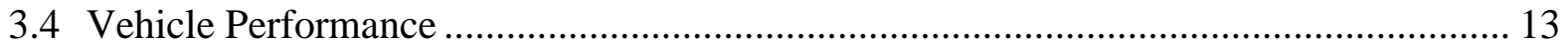

3.5 Vehicle Manufacturing and Assembly ............................................................... 14

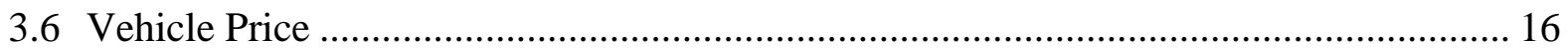

3.7 Battery Capacity and Cathode Chemistry …....................................................... 17

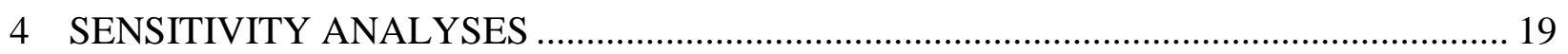

4.1 Traveler Behavior ............................................................................................ 19

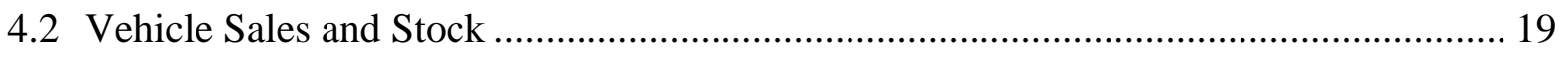

4.3 Comparable Ice Vehicles................................................................................... 21

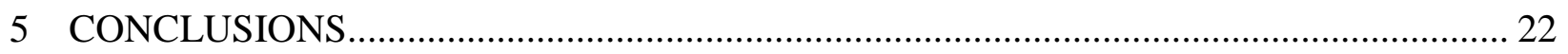

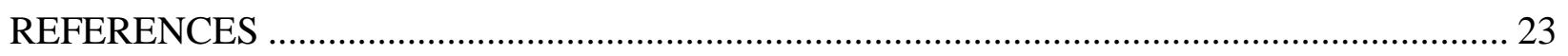




\section{FIGURES}

1 Annual sales of PEVs in the United States by year ............................................................ 3

2 Sales shares of PEVs in the United States by manufacturer, 2011-2019 ................................ 4

3 Annual electric vehicle miles assumed to be traveled by PEV type and range; total PHEV VMT included for comparison ........................................................................ 5

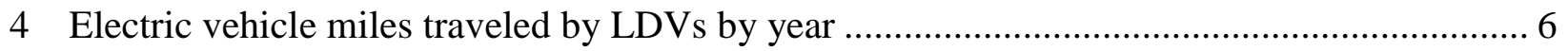

5 Electricity consumption by PEVs by year ........................................................................ 7

6 Gasoline displacement from ICE vehicles by LDV PEVs by year........................................... 8

7 Portion of key national metrics which are due to PEVs in the United States by year, 2010-2019.

8 All-electric range for PEVs. Left side: sales-weighted average of range in new vehicles sold in each month. Right side: stock-weighted average range for all on-road vehicles. 10

9 Electric efficiency for PEVs. Left side: distance-weighted average efficiency for new vehicles sold in each month. Right side: distance-weighted average for all

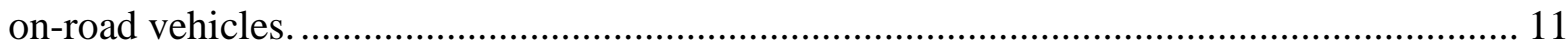

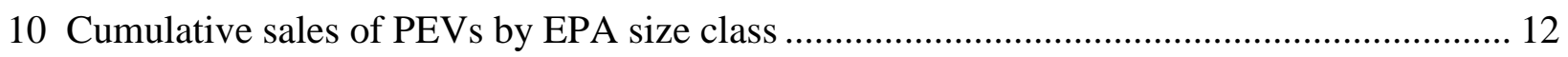

11 Average performance indicators for PEVs sold in each month............................................. 13

12 Assembly location for PEVs sold in the United States through 2019 .................................. 14

13 Assembly location by month and annual sales-weighted AALA domestic content for PEVs sold in the United States from 2010 to 2019 ..................................................... 15

14 Average MSRP for PEV sold from 2010 to 2019; average expenditure for light-duty vehicles from BEA included for comparison....................................................... 16

15 Battery capacity added each year for LDV PEVs in the United States ................................ 18

\section{TABLES}

1 Annual Sales of New PEVs, and Total Annual eVMT, Gasoline Reduction, Electricity Consumption, and $\mathrm{CO}_{2}$ Emissions Reduction by On-Road PEVs .......................... 2

2 New Lithium-Ion Battery Capacity (GWh) for BEV and PHEV Each Year Since 2010....... 18

3 Comparison of Total Gasoline Reduction and $\mathrm{CO}_{2}$ Emissions Reduction with Different ICE Vehicles for Comparison

4 Annual Sales of New PEVs, and Total Annual eVMT, Gasoline Reduction, Electricity Consumption, and $\mathrm{CO}_{2}$ Emissions Reduction by On-Road PEVs (Duplication of Table 1) 


\section{ACKNOWLEDGMENTS}

This activity was supported by the Vehicle Technologies Office, Office of Energy Efficiency and Renewable Energy, United States Department of Energy. The authors would like to thank Madhur Boloor, Kate McMahon, Rachael Nealer, and Jacob Ward for guidance and feedback.

This report was prepared as an account of work sponsored by an agency of the United States government. Neither the United States government nor any agency thereof, nor any of their employees, makes any warranty, express or implied, or assumes any legal liability or responsibility for the accuracy, completeness, or usefulness of any information, apparatus, product, or process disclosed or represents that its use would not infringe privately owned rights. Reference herein to any specific commercial product, process, or service by trade name, trademark, manufacturer, or otherwise does not necessarily constitute or imply its endorsement, recommendation, or favoring by the United States government or any agency thereof. The views and opinions of authors expressed herein do not necessarily state or reflect those of the United States government or any agency thereof. 


\section{LIST OF ACRONYMS}

$\begin{array}{ll}\text { AALA } & \text { American Automobile Labeling Act } \\ \text { BEV } & \text { Battery Electric Vehicle } \\ \text { DOE } & \text { Department of Energy } \\ \text { EPA } & \text { Environmental Protection Agency } \\ \text { eVMT } & \text { electric vehicle miles traveled } \\ \text { FHWA } & \text { Federal Highway Administration } \\ \text { GWh } & \text { gigawatt-hour } \\ \text { ICE } & \text { internal combustion engine } \\ \text { kWh } & \text { kilowatt-hour } \\ \text { LDV } & \begin{array}{l}\text { light-duty vehicle } \\ \text { Multi-Day Individual Utility Factor } \\ \text { MDIUF } \\ \text { mpg }\end{array} \\ \text { MPGe } \\ \text { mph }\end{array}$




\title{
ASSESSMENT OF LIGHT-DUTY PLUG-IN ELECTRIC VEHICLES IN THE UNITED STATES, 2010 - 2019
}

\begin{abstract}
This report examines properties of plug-in electric vehicles (PEVs) sold in the United States from 2010 to 2019, exploring vehicle sales, miles driven, electricity consumption, petroleum reduction, vehicle manufacturing, and battery production, among other factors. Over 1.4 million PEVs have been sold, driving over 37 billion miles on electricity since 2010, thereby reducing national gasoline consumption by $0.34 \%$ in 2019 and 1.4 billion gallons cumulatively through 2019. In 2019, PEVs used 4.1 terawatt-hours of electricity to drive 12.7 billion miles, offsetting 470 million gallons of gasoline. Since 2010, 69\% all PEVs have been assembled in the United States, and over 60 gigawatt-hours of lithium-ion batteries have been installed in vehicles to date.
\end{abstract}

\section{INTRODUCTION}

The market share of plug-in electric vehicles (PEVs) in light-duty vehicles has grown over the last decade as costs of lithium-ion batteries dropped while energy density improved (DOE, 2019). This report quantifies the environmental and economic effect of the growing PEV market, updating a report written last year, "Assessment of Light-Duty Plug-In Electric Vehicles in the United States, 2010-2018" (Gohlke and Zhou, 2019). Much of the methodology is similar, though estimations have been updated with improved data when possible.

While traditional gasoline- and diesel-powered internal combustion engines (ICE) are the most common light-duty drivetrain worldwide, alternative-fuel drivetrains are rapidly increasing in market share. PEV sales are among the fastest growing market shares worldwide, with over one million in operation in each of China, Europe, and the United States (DOE, 2018; Irle, 2018; EV Volumes, 2017a), and over two million sales worldwide in 2019 (Pontes, 2020). PEVs get at least a portion of their energy from electricity which is supplied to the vehicle through a charging cable. There are two types of PEVs: battery electric vehicles (BEVs) are powered exclusively by electricity, while plug-in hybrid electric vehicles (PHEVs) have a battery as well as a separate internal combustion engine for extended driving range.

Understanding the aggregate impact of electric vehicles is important when exploring electricity use and petroleum consumption. Electric utilities are working to understand the changes in electricity generation, demand, and required infrastructure (EEI, 2018; SEPA, 2017; Szinai, 2020). The growth of electric vehicles can offset petroleum consumption by conventional internal combustion engine vehicles, affecting oil prices and extraction (OPEC, 2018). Refineries need to know the potential impact on demand for their refining mix; gasoline and diesel are the two most common end products in the United States (DOE, 2017). 
Table 1 summarizes the high-level national impacts of these plug-in electric vehicles for PEV sales, electric vehicle miles traveled (eVMT), gasoline displacement, electricity consumption, and reductions in carbon dioxide emissions in each year from 2011 to 2019. As the market for PEV has grown along with the total on-road vehicles, each of these quantities has grown since 2011. Through 2019, over 1.4 million PEVs have been sold in the United States and have driven 37 billion miles, displacing more than 1.4 billion gallons of gasoline and nearly 7 million metric tons of $\mathrm{CO}_{2}$, and consuming over 12 terawatt-hours of electricity.

TABLE 1 Annual Sales of New PEVs, and Total Annual eVMT, Gasoline Reduction, Electricity Consumption, and $\mathrm{CO}_{2}$ Emissions Reduction by On-Road PEVs

\begin{tabular}{|cccccc|}
\hline Year & $\begin{array}{c}\text { PEV sales } \\
\text { (thousands) }\end{array}$ & $\begin{array}{c}\text { eVMT } \\
\text { (billion miles) }\end{array}$ & $\begin{array}{c}\text { Gasoline reduction } \\
\text { (million gallons) }\end{array}$ & $\begin{array}{c}\text { Electricity } \\
\text { consumption } \\
\text { (gigawatt-hours) }\end{array}$ & $\begin{array}{c}\mathrm{CO}_{2} \text { emissions } \\
\text { reduction } \\
\text { (million metric tons) }\end{array}$ \\
\hline & & & & & \\
2011 & 18 & 0.1 & 2 & 20 & 0.01 \\
2012 & 53 & 0.3 & 12 & 110 & 0.05 \\
2013 & 97 & 1.0 & 37 & 330 & 0.17 \\
2014 & 119 & 1.9 & 72 & 650 & 0.33 \\
2015 & 114 & 3.0 & 110 & 1,000 & 0.53 \\
2016 & 160 & 4.3 & 160 & 1,400 & 0.77 \\
2017 & 196 & 6.0 & 230 & 2,000 & 1.10 \\
2018 & 361 & 8.6 & 320 & 2,800 & 1.60 \\
\hline 2019 & 327 & 12.7 & 470 & 4,100 & $\mathbf{6 . 9 0}$ \\
\hline Total & $\mathbf{1 , 4 4 0}$ & $\mathbf{3 7 . 9}$ & $\mathbf{1 , 4 1 0}$ & $\mathbf{1 2 , 5 0 0}$ & \\
\hline
\end{tabular}

The source data used in this assessment is compiled largely from publicly available data. Including these data in one report allows for convenient reference and harmonization of assumptions on vehicle use. Compiling data on vehicle sales and characteristics allows for a comprehensive assessment of the historical impacts of PEVs in the United States. Sales estimates for this analysis come from Argonne National Laboratory (ANL, 2020). The all-electric range, vehicle efficiency, size class, electric motor power, and manufacturer's suggested retail price (MSRP) of each model come from the FuelEconomy.gov database, managed by the U.S. Department of Energy (DOE) and Environmental Protection Agency (EPA) (DOE and EPA, 2020). These terms are used to quantify eVMT, gasoline reduction, electricity consumption, and emissions reductions, as presented in Table 1. Vehicle assembly and origin of parts come from American Automobile Labeling Act (AALA) data from the National Highway Traffic Safety Administration (NHTSA) (NHTSA, 2019), and are supplemented by manufacturer press releases and news stories. Vehicle acceleration and battery capacity for each vehicle were established through a mix of data compiled by InsideEVs (Kane, 2019), press releases, news stories, and information on manufacturer websites.

Section 2 of this report highlights national scale impacts of the electric vehicle fleet. Section 3 explores how characteristics of PEVs have evolved over time. Section 4 presents a detailed sensitivity analysis on several assumptions, including vehicle sales, battery size, and driving behavior, to test the robustness of the results, and Section 5 summarizes key findings. 


\section{NATIONAL-LEVEL IMPACTS}

This section presents total national-scale metrics for PEVs, including vehicle sales, miles traveled, electricity consumed, gasoline displacement and carbon dioxide emissions. These numbers are then placed in a broader national context to show the impacts of PEVs.

\subsection{PEV SALES}

Nearly one-and-a-half million PEVs have been sold in the United States since 2011. Over 325,000 plug-in electric vehicles were sold in the United States in 2019, a 10\% decrease from 2018. Sales of all-electric BEVs grew $2 \%$ to 238,000 , while PHEV sales decreased by over $30 \%$ to 88,000 . The historic growth in PEV sales is shown in Figure 1. Through 2019, a total of more than 1,400,000 PEVs have been sold, 59\% of which have been BEVs. Before 2018, cumulative sales of PHEVs were slightly higher than of BEVs. In 2019, the decline in PHEV sales coupled with growth in BEV sales, particularly the Tesla Model 3, led to BEVs comprising $73 \%$ of the PEV market.

\section{Annual PEV Sales}

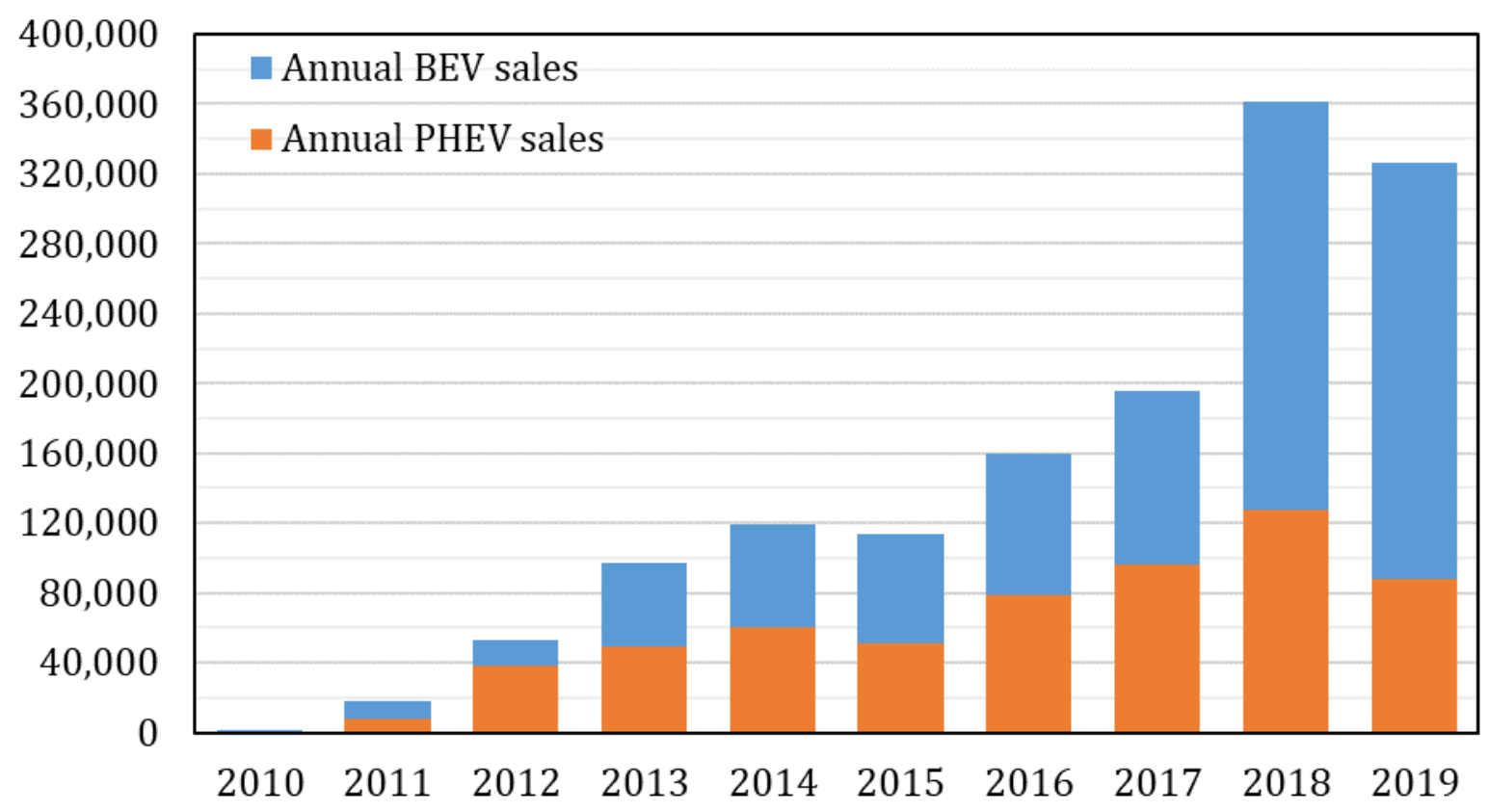

\section{FIGURE 1 Annual sales of PEVs in the United States by year}

From 2011 to 2019, annual PEV sales grew from fewer than 18,000 to more than 325,000 , equivalent to an average year-over-year growth rate of 44\%. In 2019, PEV sales comprised $1.9 \%$ of the total national sales of new light-duty vehicles (DOE, 2020). As of 2019, eleven models of plug-in electric vehicles have sold more than 30,000 units in the United States: Tesla Model 3, Tesla Model S, Chevrolet Volt, Nissan Leaf, Toyota Prius, Tesla Model X, Ford 
Fusion Energi, Chevrolet Bolt, BMW i3, Ford C-Max Energi, and the Honda Clarity PHEV. Of these, the Volt, Model S, Model 3, Leaf, and plug-in Prius have all sold more than 100,000 units. For the second consecutive year, the Tesla Model 3 was the top-selling PEV in 2019; more than 150,000 of these vehicles were sold in 2019.

Figure 2 shows the percentage of all PEV sales by each automaker. Tesla, with 3 models in the overall top ten of U.S. sales, has the most sales with $38 \%$ of all of PEVs. General Motors and Nissan also each have at least $10 \%$ of domestic PEV sales.

\section{PEV sales shares by automaker}

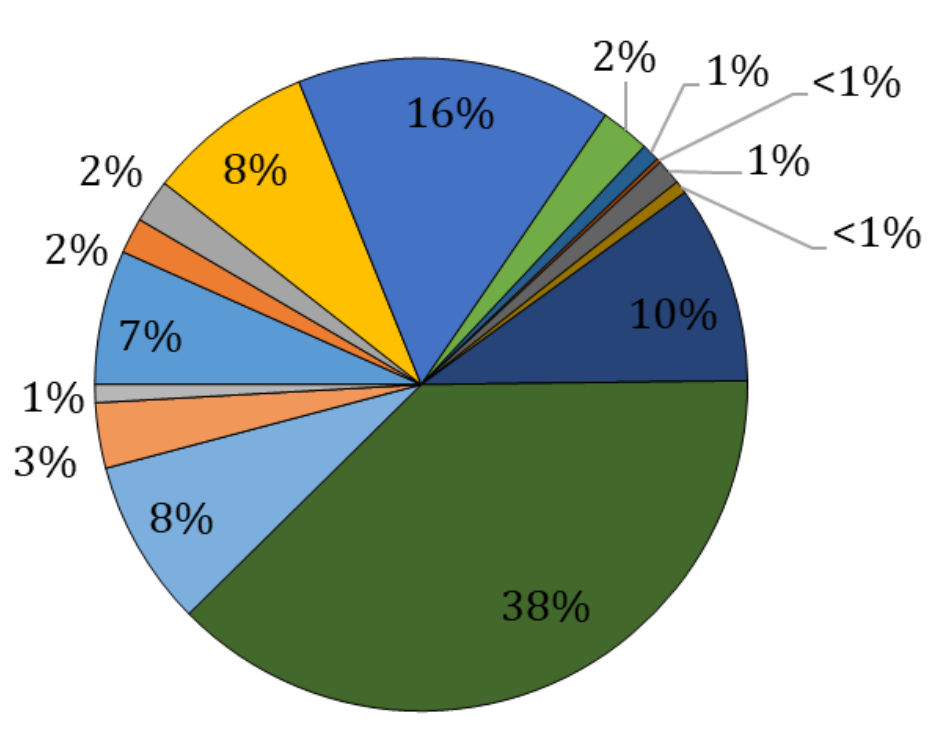

$\square$ BMW
$\square$ Daimler
$\square$ FCA
$\square$ Ford
$\square$ General Motors
$\square$ Honda
$\square$ Hyundai
$\square$ Jaguar
$\square$ Kia
$\square$ Mitsubishi
$\square$ Nissan
$\square$ Tesla
$\square$ Toyota
$\square$ Volkswagen
$\square$ Volvo

FIGURE 2 Sales shares of PEVs in the United States by manufacturer, 2011-2019

\subsection{ELECTRIC MILES TRAVELED}

The total annual vehicle miles traveled (VMT) for each PEV depends on traveler behavior and the vehicle's all-electric range. In this analysis, PHEVs are assumed to drive the same total annual distance as ICE vehicles, with miles not supplied by electricity powered by gasoline like a hybrid. Conversely, the estimated annual mileage of each BEV is reduced relative to a comparable ICE vehicle in order to account for the limited driving range. To determine the driving behavior of similar ICE vehicles, we note that since PEVs are an emerging technology, these vehicles are on average newer than the average ICE vehicle. As of December 2019, the average age of an on-road electric vehicle was 2.8 years old. According to mileage schedules from NHTSA and the EPA (Lu, 2006; EPA, 2016; NHTSA and EPA, 2018) and results from the National Household Travel Survey (Santos et al., 2011; McGuckin and Ford, 2018), the average ICE car is driven approximately 13,000-14,000 miles per year in its first three years. Therefore, as a baseline for this report, an annual driving distance of 13,500 miles per vehicle is used. 
PHEVs can travel using a mix of gasoline and electricity. Because of the flexibility of a secondary fuel source, PHEVs are assumed to drive the same total distance as ICE vehicles, i.e., 13,500 miles per year (Gohlke \& Zhou, 2019). For PHEVs, the utility factor represents the fraction of total mileage run on electricity rather than gasoline. This utility factor is a function of the battery size; a battery with a longer all-electric range will have a higher fraction of miles driven using electricity. The utility factor for PHEVs in this report comes from the Society of Automotive Engineers (SAE) J2841 standard (SAE, 2010), specifically the multi-day individual utility factor (MDIUF).

BEVs do not have a utility factor, as $100 \%$ of their driving is all-electric. BEVs have been found to generally drive less than PHEVs and ICE vehicles, though the majority of vehicles studied have all-electric ranges less than 150 miles (CARB, 2017a; CARB, 2017b; Carlson, 2015; Nicholas et al., 2017; Plötz et al., 2017; Smart and Salisbury, 2015). BEVs with longer ranges (e.g. Tesla Model S) have been found to drive comparable annual miles to PHEV and ICE vehicles. Some studies have even found BEVs with increased mileage (CARB, 2017a; Figenbaum and Kolbenstvedt, 2016). To account for the correlation of annual driving distance with driving range, we adjust the annual mileage for each vehicle dependent on its reported allelectric range, as if there is an effective utility factor for eVMT. This analysis uses the square of the utility factor for PHEVs as the effective utility factor for BEV, which has good agreement with real-world studies. ${ }^{1}$ Empirically, the squared PHEV utility factor is very similar to an allelectric utility factor derived from National Household Travel Survey (NHTS) responses (Duoba, 2013). The utility factor for PHEVs and effective utility factor for BEVs are shown in Figure 3.

\section{Assumed driving for PHEV and BEV}

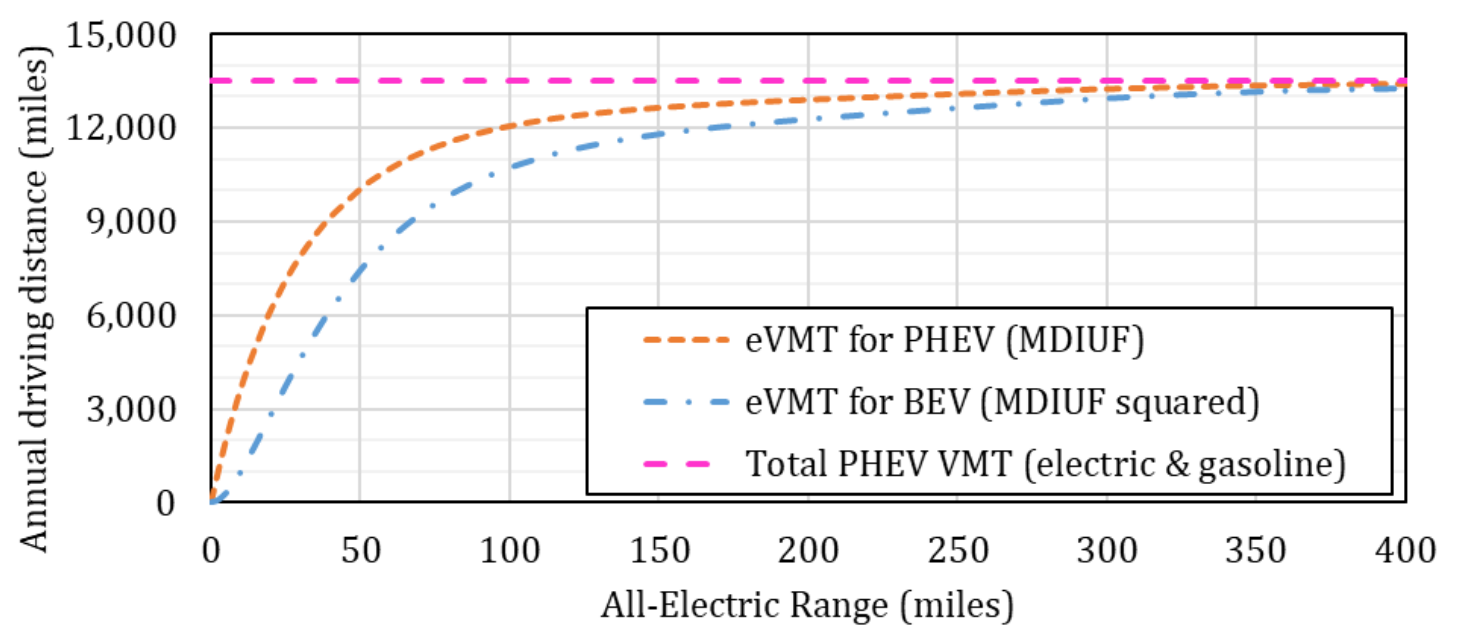

FIGURE 3 Annual electric vehicle miles assumed to be traveled by PEV type and range; total PHEV VMT included for comparison

\footnotetext{
1 Multiple different functions were compared against data from the above references and from the 2017 NHTS. Squaring the MDIUF utility factor for PHEV yields a better least-squared fit of annual VMT for BEV than any linear scaling factor of the MDIUF, matching the real-world data better for long-range BEVs.
} 
Given the total number of monthly PEV sales as well as the all-electric range and the effective utility factor for each vehicle, the total mileage driven in all-electric mode across the entire national light duty vehicle (LDV) fleet can be estimated. Figure 4 shows the total eVMT by year in the United States. Through 2019, more than 37 billion miles have been driven powered by electricity. In 2019, 12.7 billion miles on the road were driven by light duty electric vehicles using electric power; approximately $68 \%$ of this was driven by BEVs. The average BEV in 2019 drove 12,100 miles, while the average PHEV drove 7,400 eVMT.

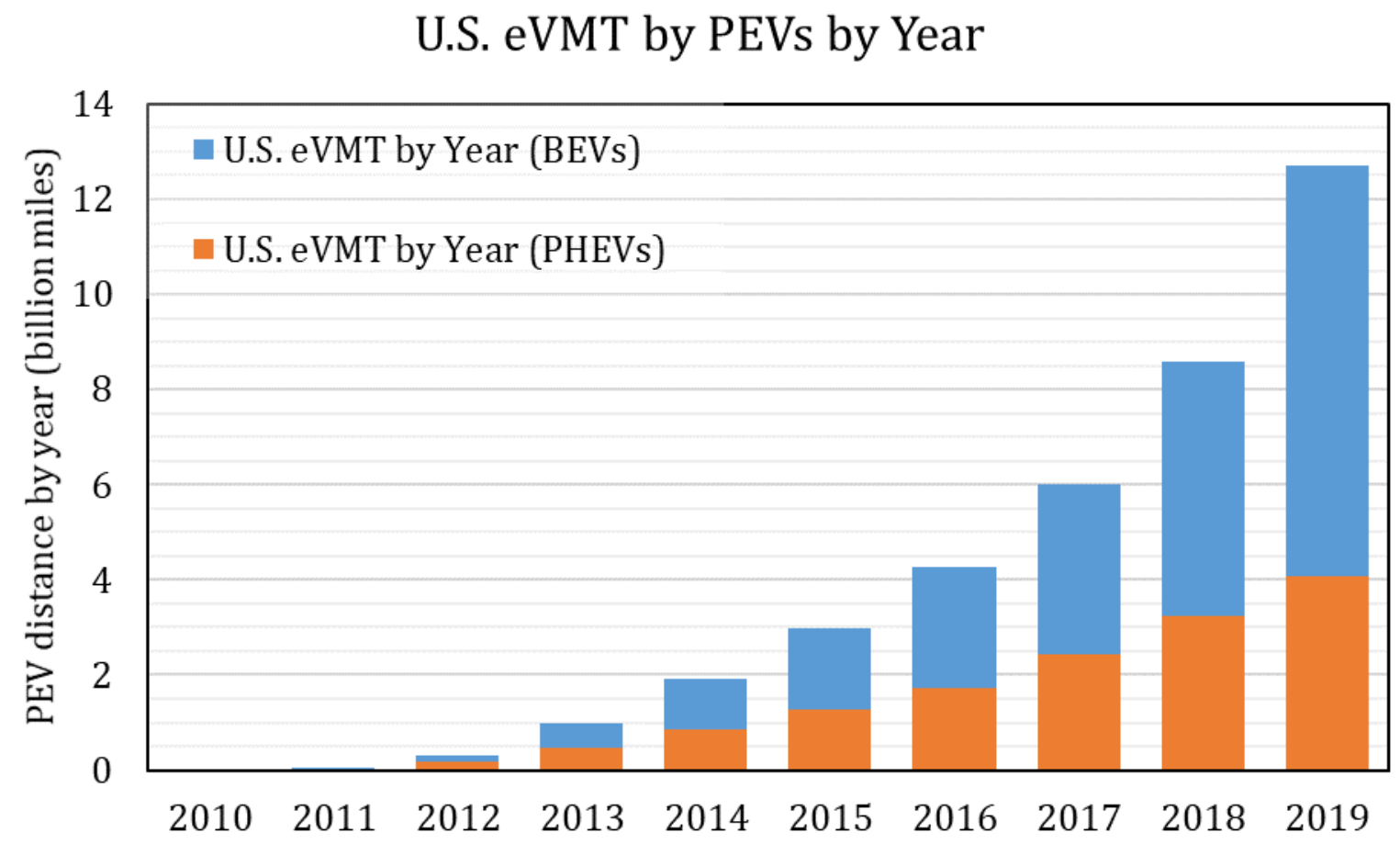

FIGURE 4 Electric vehicle miles traveled by LDVs by year

\subsection{ELECTRICITY CONSUMPTION BY PEVs}

Combining eVMT with knowledge of vehicle electricity efficiency allows us to determine the total electricity consumption by PEVs in the United States, shown in Figure 5. To find the total electricity consumption, the estimated eVMT in each month is multiplied by the electricity consumption per mile for each vehicle model. Through 2019, a total of 12.5 terawatthours of electricity have been consumed by PEVs. In 2019, the total electricity use for LDVs on the road was 4.1 terawatt-hours. In 2019, the average PHEV consumed 2,560 kilowatt-hours $(\mathrm{kWh})$ of electricity, and the average BEV consumed 3,770 kWh of electricity. 


\section{Electricity Consumption by PEVs by Year}

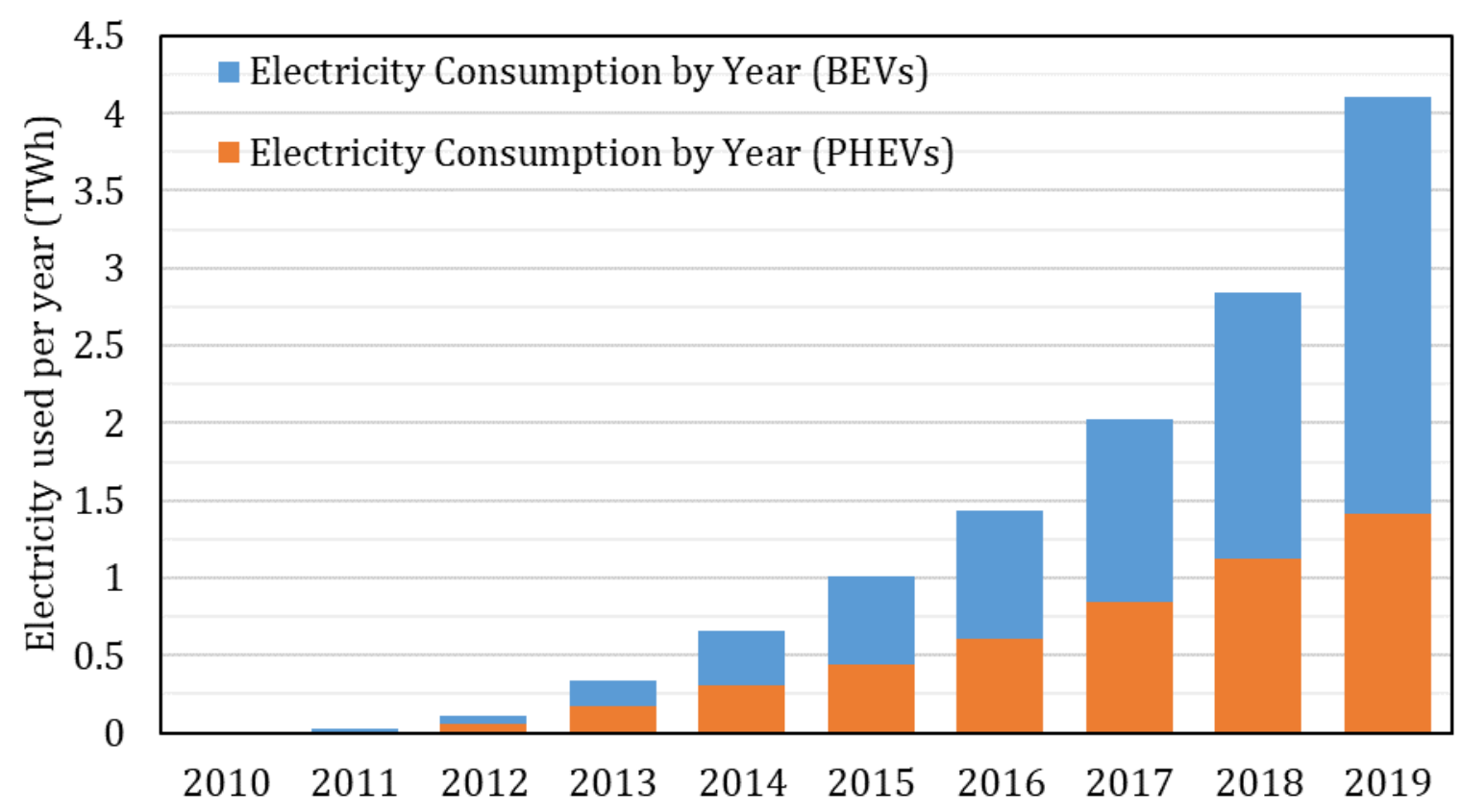

FIGURE 5 Electricity consumption by PEVs by year

\subsection{GASOLINE CONSUMPTION REDUCTION}

Use of electricity by PEVs displaces gasoline that would otherwise be used by an ICE vehicle. ${ }^{2}$ To estimate this reduction in gasoline consumption, we need to make assumptions about how each mile would have otherwise been traveled. For each PEV, we select a comparable ICE in the same size class and model year in order to calculate the gasoline consumption offset by using electricity. ${ }^{3}$ For example, a compact PEV offsets the fuel consumption of a compact ICE vehicle, rather than comparing with a fleet-wide average. Given the tendency for early adopters of electric vehicles to be interested in fuel economy and environmental benefits, the comparable gasoline ICE vehicle was assumed to be more fuel efficient than average, specifically, the 75th percentile of models available in that year in that size class. ${ }^{4}$ Section 4 examines the impact of varying the fuel economy of this reference vehicles.

The total gasoline displacement by year is graphed in Figure 6. In 2019, 470 million gallons of gasoline were offset by PEVs, with 70\% of this total offset by BEVs. In 2019, the

2 This analysis only counts gasoline usage that is offset when the car is operating in electric mode. For PHEVs operating in charge-sustaining mode (i.e., using only gasoline), the hybrid engines are also generally more efficient than the average ICE vehicle, but this reduction in gasoline is not calculated here.

3 For each model year and each size class, vehicle fuel efficiencies were gathered from the FuelEconomy.gov database (DOE and EPA, 2020).

4 Since the 'Two seater' classification is largely high-performance sports cars, the Smart Fortwo Electric Drive was compared directly with the ICE version of the same vehicle instead of the remainder of the vehicles in that size class. 
average on-road BEV offset 460 gallons of gasoline, and the average PHEV offset 260 gallons. Cumulatively, through 2019, PEVs have offset over 1.4 billion gallons of gasoline, 910 million gallons by BEVs and 500 million gallons by PHEVs.

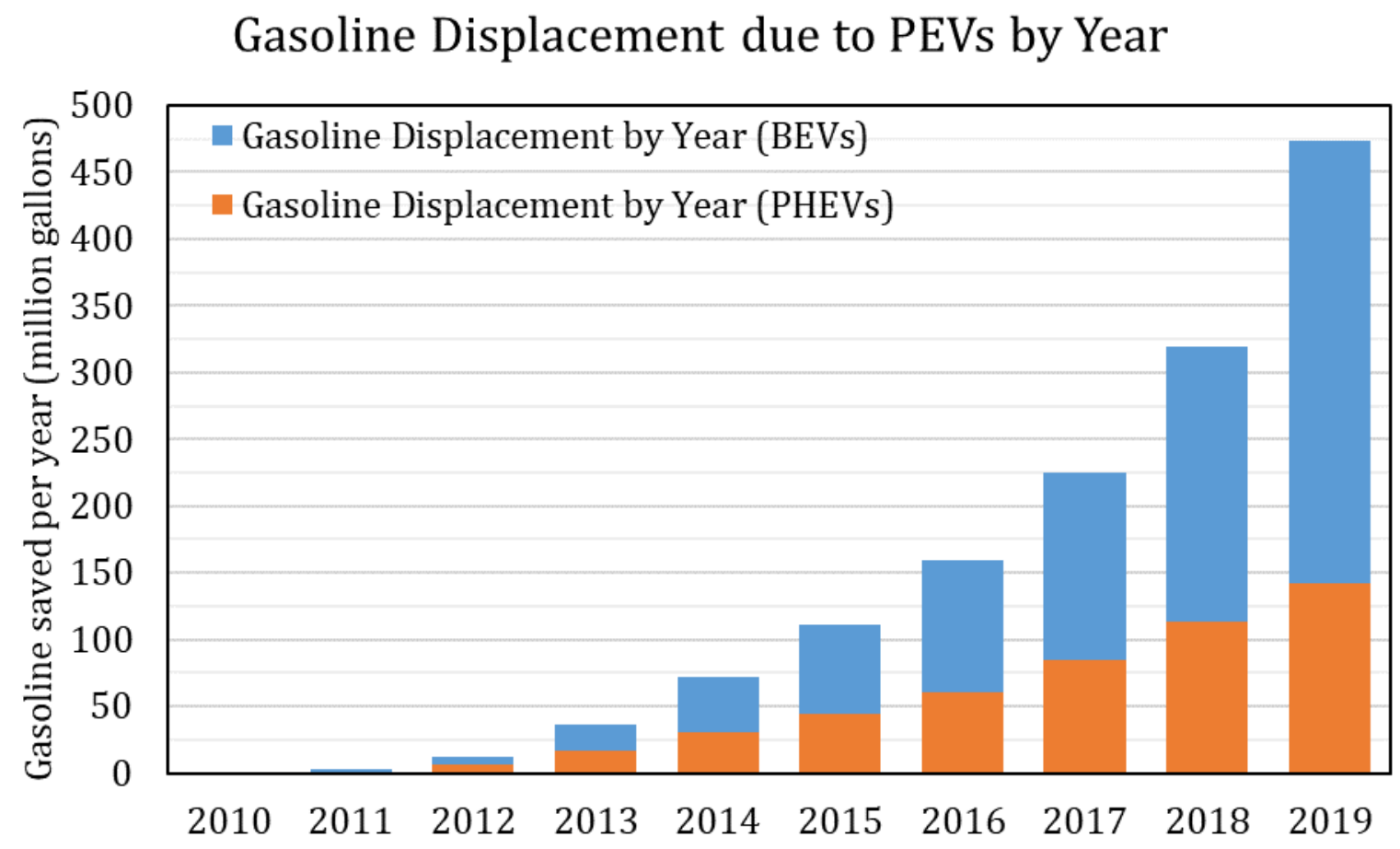

FIGURE 6 Gasoline displacement from ICE vehicles by LDV PEVs by year

\subsection{CARBON DIOXIDE EMISSIONS}

Operation of PEVs reduces emissions as well. The EPA states that combustion of each gallon of gasoline emits 8,887 grams of $\mathrm{CO}_{2}$ (EPA and DOT, 2010). ${ }^{5}$ The amount of tailpipe emissions from an ICE vehicle can be found by multiplying the miles driven by 8,887 grams $\mathrm{CO}_{2}$ / gallon of gasoline and dividing by the fuel economy (in miles per gallon, or mpg). While the carbon content of gasoline is constant, emissions from electricity production have been decreasing. According to the EPA, electricity production in the United States emitted an average of 430 grams of $\mathrm{CO}_{2}$ per kilowatt-hour in 2018 (EPA, 2020), down $23 \%$ from the $559 \mathrm{~g} \mathrm{CO}_{2}$ / $\mathrm{kWh}$ emitted in 2010. The emissions to drive an electric vehicle are found by multiplying the miles driven by the electricity consumption (in $\mathrm{kWh}$ per mile) by the emission rate. As an example, an ICE vehicle consuming $30 \mathrm{mpg}$ emits $300 \mathrm{~g} \mathrm{CO}_{2} /$ mile, while a $\mathrm{BEV}$ consuming

5 This calculation is for tailpipe emissions only; that is, it excludes upstream effects for refining and transportation of the fuel, as well as emissions from the production of the vehicles. For electric vehicles, the calculation is for the generation of the electricity for vehicle operation, again excluding vehicle manufacturing. The majority of emissions come from the operation, rather than the manufacturing, of both ICE vehicles and PEVs. A recent study found that tailpipe emissions from a midsize gasoline ICE vehicle were $68 \%$ of the total lifetime emissions, while electricity consumption for operation was responsible for $77 \%$ of the emissions from a midsize BEV (Elgowainy et al., 2016). 
$0.33 \mathrm{kWh} /$ mile in 2018 was responsible for $142 \mathrm{~g} \mathrm{CO}_{2}$ / mile. Assuming the U.S. national grid average for emissions from electricity production, and comparing each PEV with the $75^{\text {th }}$ percentile ICE vehicle for fuel economy in its size class in each year, PEVs have offset a total of 6.9 million metric tons of carbon dioxide during vehicle operation.

\subsection{CONTEXTUAL COMPARISONS}

PEVs are a growing share of the vehicle market and are having increasing impacts on the transportation and energy sectors. Figure 7 highlights how these impacts have changed, comparing the quantities from PEVs for total number of on-road vehicles, miles driven, electricity consumption, and gasoline reduction with corresponding total national values. ${ }^{6}$ In 2018, PEVs comprised $0.44 \%$ of the 250 million light-duty vehicle registrations (FHWA, 2019a). Nearly 3 trillion miles are driven by light-duty vehicles each year (FHWA, 2019b); in $20180.29 \%$ of that total was powered by electricity. In 2018, the total electricity use for LDVs on the road was 2.8 terawatt-hours. This compares with a total of 4,004 terawatt-hours (EIA, 2019), or $0.071 \%$ of the total national electricity generation. In 2018, 320 million gallons of gasoline were offset by PEVs, equivalent to $0.23 \%$ of the 138 billion gallons of gasoline used in the United States that year (EIA, 2019).

\section{PEV share of national totals}

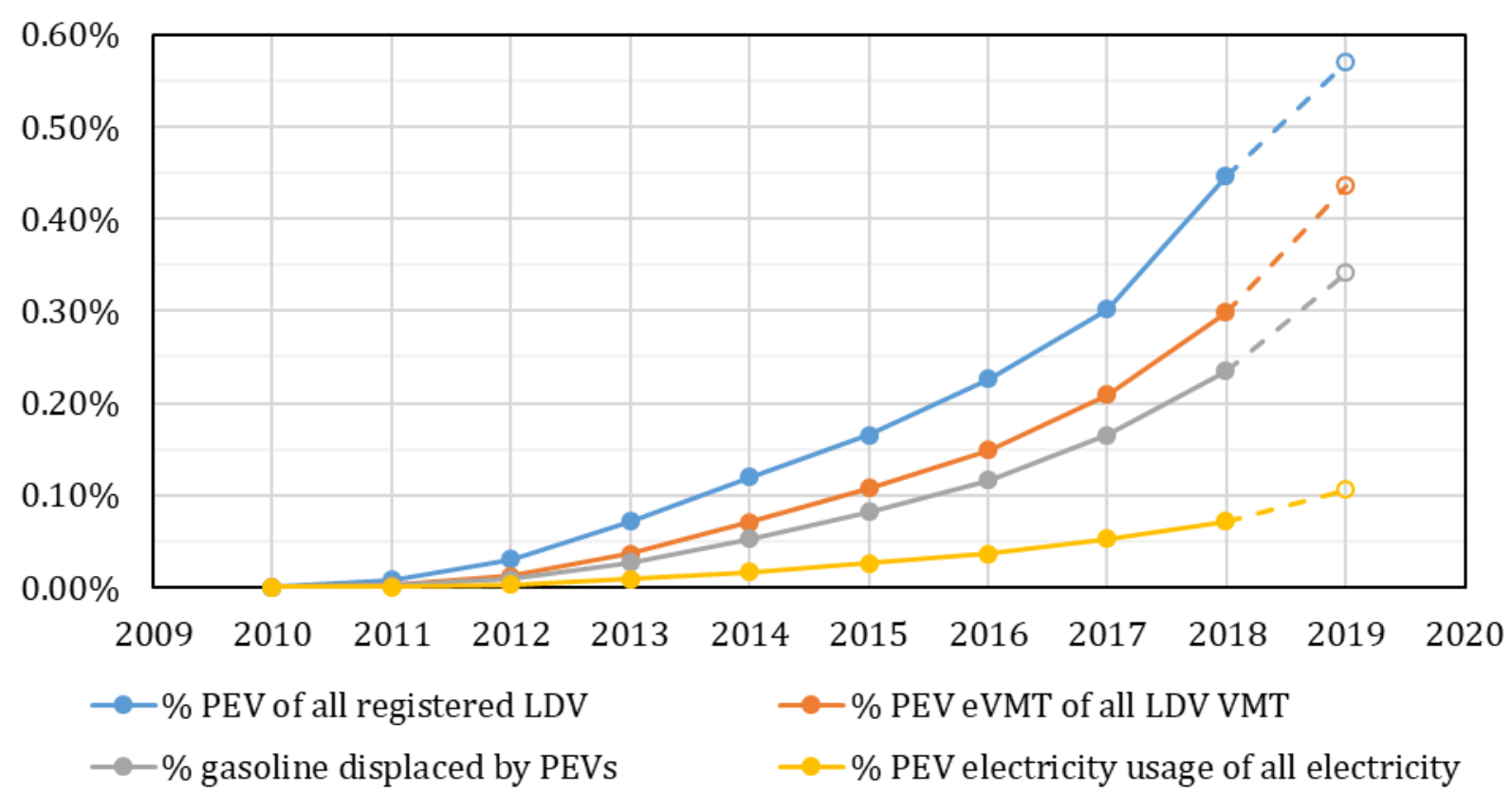

FIGURE 7 Portion of key national metrics which are due to PEVs in the United States by year, 2010-2019

6 For most national data, 2018 is the latest year with full data availability as of the writing of this report (May 2020), so Figure 7 uses extrapolated values of vehicle registrations, VMT, gasoline consumption, and electricity consumption to estimate through 2019. 


\section{VEHICLE CHARACTERISTICS}

In addition to the total national-scale impacts of PEVs presented in Section 2, specific trends within the PEV market can be examined, including all-electric range, energy efficiency, vehicle size, performance, battery size, and manufacturing location.

\subsection{ALL-ELECTRIC RANGE}

The average range of PEVs has increased since 2010. This is largely due to the introduction and increased consumer preference of longer-range BEVs, which have become more economical due to the reduced cost of batteries. Figure 8 shows the average sales-weighted all-electric range for new vehicles (left side) and for all on-road vehicles (right side). PHEVs have consistently averaged between 20 and 35 miles of all-electric range while the average range of BEVs has grown from approximately 70 miles to over 200 miles. The sharp growth in allelectric range for BEVs in early 2013 is due to the introduction of the Tesla Model S, with a range of up to 265 miles, while the increase in 2018 is largely due to high sales of the Tesla Model 3 with a range of up to 310 miles. In 2019, the sales-weighted range for new PEVs was 210 miles - 30 miles for PHEV and 290 miles for BEV.
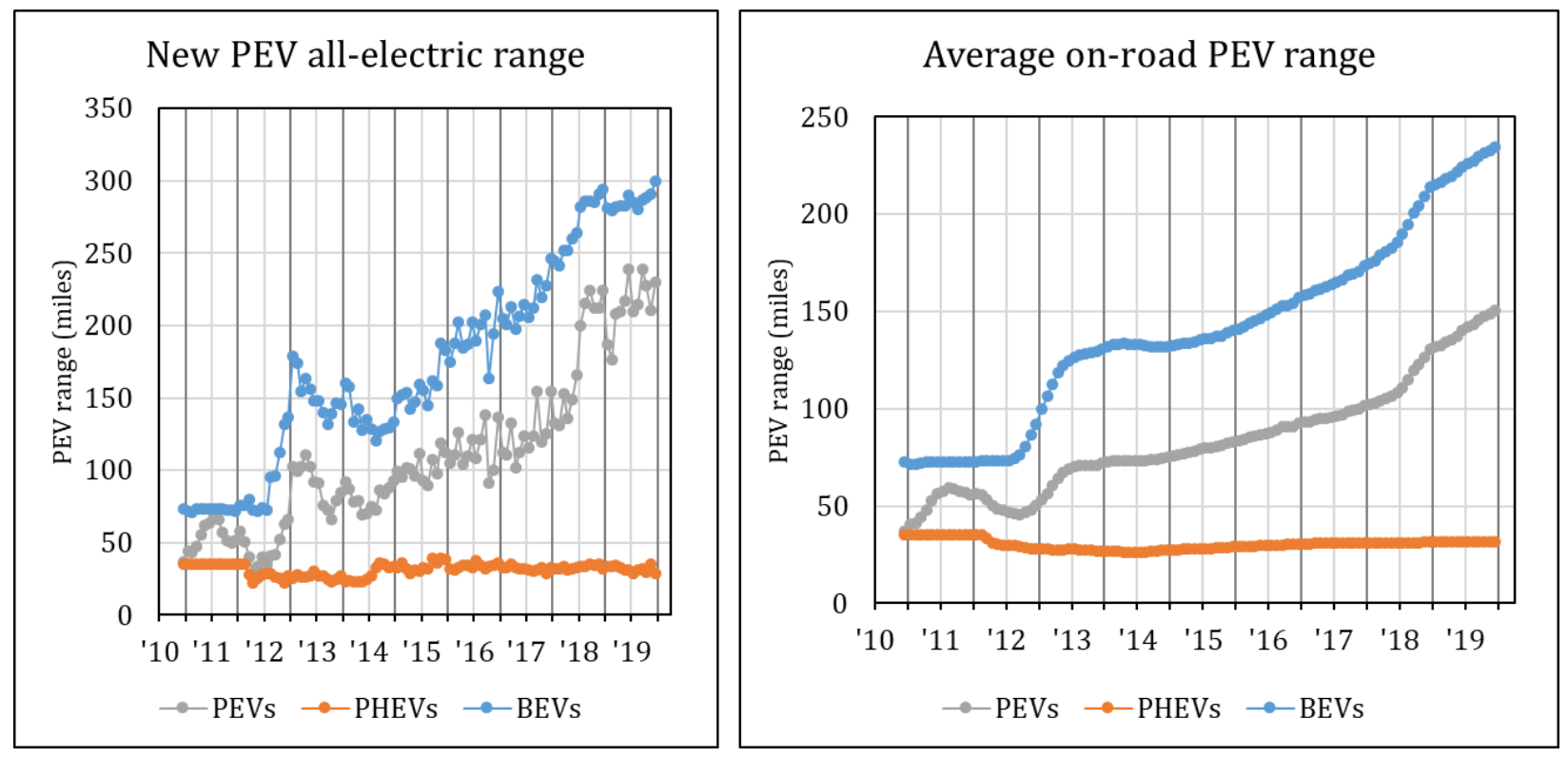

FIGURE 8 All-electric range for PEVs. Left side: sales-weighted average of range in new vehicles sold in each month. Right side: stock-weighted average range for all on-road vehicles. 


\subsection{ENERGY EFFICIENCY}

Figure 9 shows the average (distance-weighted) energy efficiency of vehicles running on electricity for new vehicles (left) and the entire on-road fleet of PEVs (right). ${ }^{7}$ Since 2010, vehicles have become more efficient on average. Variability in the sales mix leads to relatively large changes in average electricity consumption month-to-month for newly purchased PEVs, while the average of the entire PEV fleet has had smaller monthly variability.
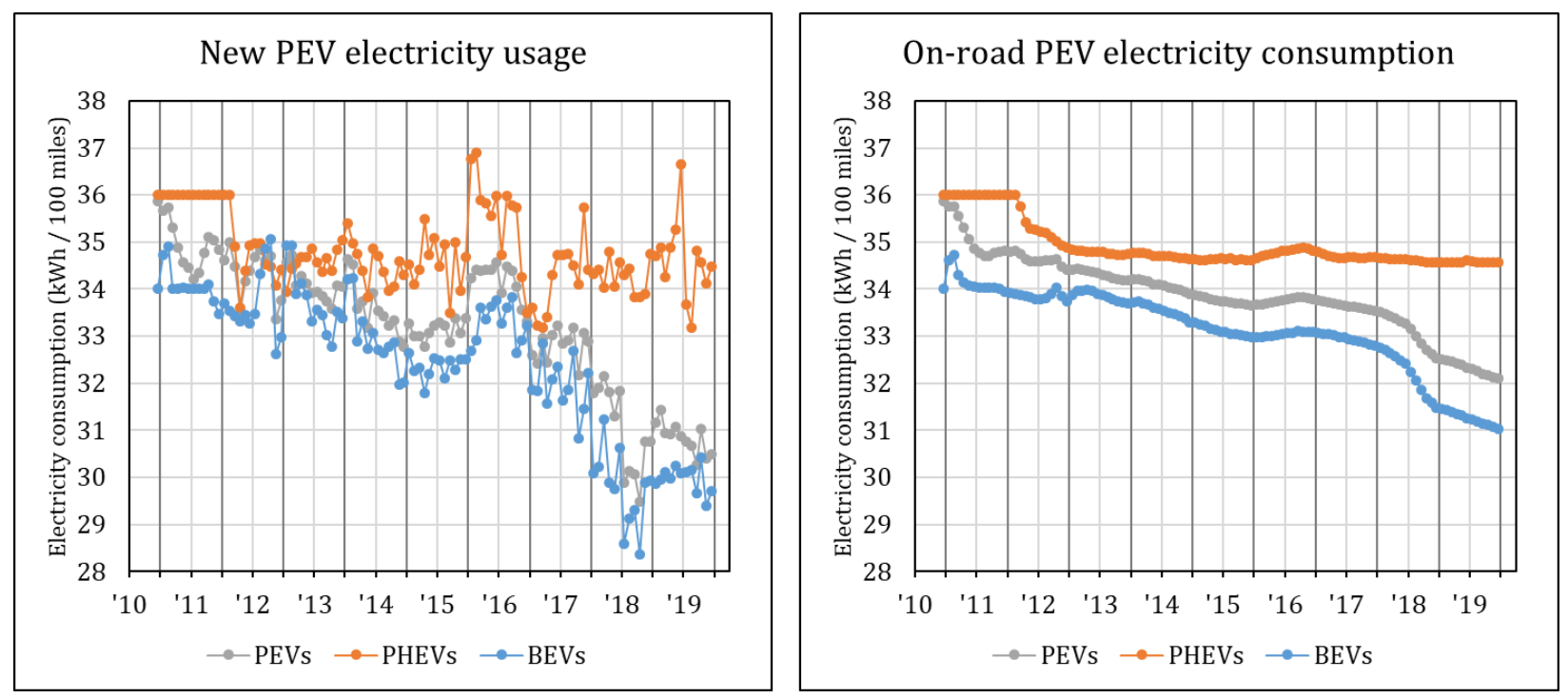

FIGURE 9 Electric efficiency for PEVs. Left side: distance-weighted average efficiency for new vehicles sold in each month. Right side: distance-weighted average for all on-road vehicles.

The average electricity consumption of the entire PEV fleet has dropped from nearly 36 $\mathrm{kWh}$ per 100 miles to approximately $32 \mathrm{kWh}$ per 100 miles. BEVs sold in the United States have generally been more efficient than PHEVs. As of December 2019, the average on-road PHEV consumed $34.6 \mathrm{kWh}$ per 100 miles driven in charge-depleting (all-electric) mode, while the average on-road BEV consumed $31.0 \mathrm{kWh}$ per 100 miles. $^{8}$ In terms of miles per gallon of gasoline equivalent (MPGe), where 33.7 kilowatt-hours of electricity is equivalent to one gallon of gasoline (EPA, 2011), the average PEV fuel economy has increased from 94 MPGe to 105 MPGe.

For new vehicles sold in 2019, BEVs used $30.0 \mathrm{kWh}$ per 100 miles driven, PHEVs averaged $34.6 \mathrm{kWh}$ per 100 miles, and the fleetwide average was $30.8 \mathrm{kWh}$ per 100 miles. As with the all-electric range, the rapid changes in 2018 and 2019 were due to high sales of the efficient Tesla Model 3, which averages approximately $28 \mathrm{kWh}$ per 100 miles across all trim levels. Through model year 2019, the most efficient vehicles in the FuelEconomy.gov database are the Hyundai Ioniq BEV and Toyota Prius Prime PHEV, each consuming $25 \mathrm{kWh} / 100$ miles when operating on electricity (DOE and EPA, 2020).

\footnotetext{
7 A distance-weighted average (rather than a sales-weighted average) is used to give a proper comparison of electricity consumption of the entire PEV fleet.

8 The per-mile energy consumption of PHEV is higher when accounting for miles powered by the ICE.
} 


\title{
3.3 SIZE CLASS AND VEHICLE WEIGHT
}

Figure 10 shows PEVs sorted by size class. The most common vehicle each year for PEV sales has been a midsize car, which includes the Nissan Leaf, Toyota Prius Prime, and Tesla Model 3. This is followed by compact cars, which are more prominent for PHEVs, such as the Chevrolet Volt, and by large cars, such as the Tesla Model S BEV. Sales for sport utility vehicle (SUV) PEVs are growing, with standard four-wheel drive SUV (including the Tesla Model X) being the second-best-selling size class of 2019.

\section{On-road PEVs by size class}

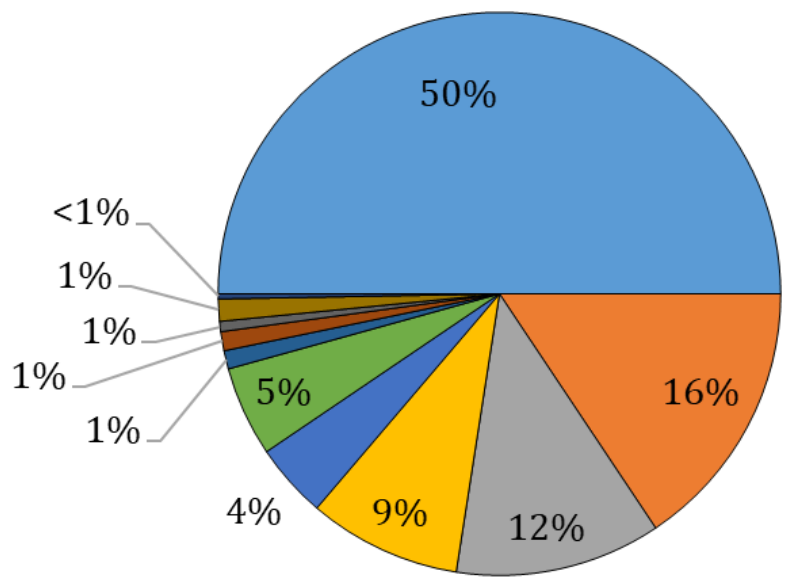

\author{
$\square$ Midsize Cars \\ $\square$ Compact Cars \\ $\square$ Large Cars \\ $\square$ Standard Sport Utility Vehicle 4WD \\ $\square$ Subcompact Cars \\ $\square$ Small Station Wagons \\ $\square$ Minicompact Cars \\ $\square$ Minivan - 2WD \\ $\square$ Two Seaters \\ $\square$ Small Sport Utility Vehicle 4WD \\ - Small Sport Utility Vehicle 2WD
}

\section{FIGURE 10 Cumulative sales of PEVs by EPA size class}

The EPA splits LDVs into five different vehicle types: cars, car SUVs, truck SUVs, minivans/vans, and pickup trucks (EPA, 2019b). Vehicles defined as cars by the EPA make up 89\% of total PEV sales, and 10\% of PEV sales have been SUVs. In 2019, car SUVs comprised $9 \%$ of BEV sales. Truck SUVs were 14\% of PHEV sales and minivans/vans were more than $6 \%$ of PHEV sales.

The EPA collects data on vehicle weights as part of the fuel economy testing process. The EPA maintains a publicly accessible database of the equivalent test weight of each vehicle, classified into 125- and 250-pound groups (EPA, 2019a). ${ }^{9}$ The sales-weighted average of these equivalent test weights for PEVs has increased from 3,800 pounds in 2011 to 4,400 pounds in 2019. Over that timeframe, the sales-weighted average equivalent test weight has increased from 3,700 pounds to 4,500 pounds for BEVs, and from 4,000 to 4,200 pounds for PHEVs. This weight increase is due to increased battery capacity in BEVs and due to larger average size classes for both BEVs and PHEVs.

9 Because of this grouping of vehicles in the EPA database, the equivalent test weight group for each vehicle is similar to, but not exactly the same as, its test weight basis. 


\subsection{VEHICLE PERFORMANCE}

Performance of electric vehicles has on average increased since 2010, as measured by electric motor power (in kilowatts) and by the acceleration time from 0 to 60 miles per hour (mph). Figure 11 shows the average total electric motor size and acceleration for PEVs sold in each year. For each of these metrics, much of the increase in vehicle performance for BEVs has been due to Tesla. The (sales-weighted) average motor size for a Tesla BEV has increased to nearly $300 \mathrm{~kW}$ and to $150 \mathrm{~kW}$ for BEVs sold by other automakers. For the Tesla vehicles, the total motor power is increased by having separate motors for front and rear wheels for their allwheel drive variants. ${ }^{10}$ Since 2014, the average electric motor size for PHEV has remained steady at around $90 \mathrm{~kW}$; PHEVs have an additional gasoline-powered engine for propulsion, and therefore have less need for a larger electric motor.
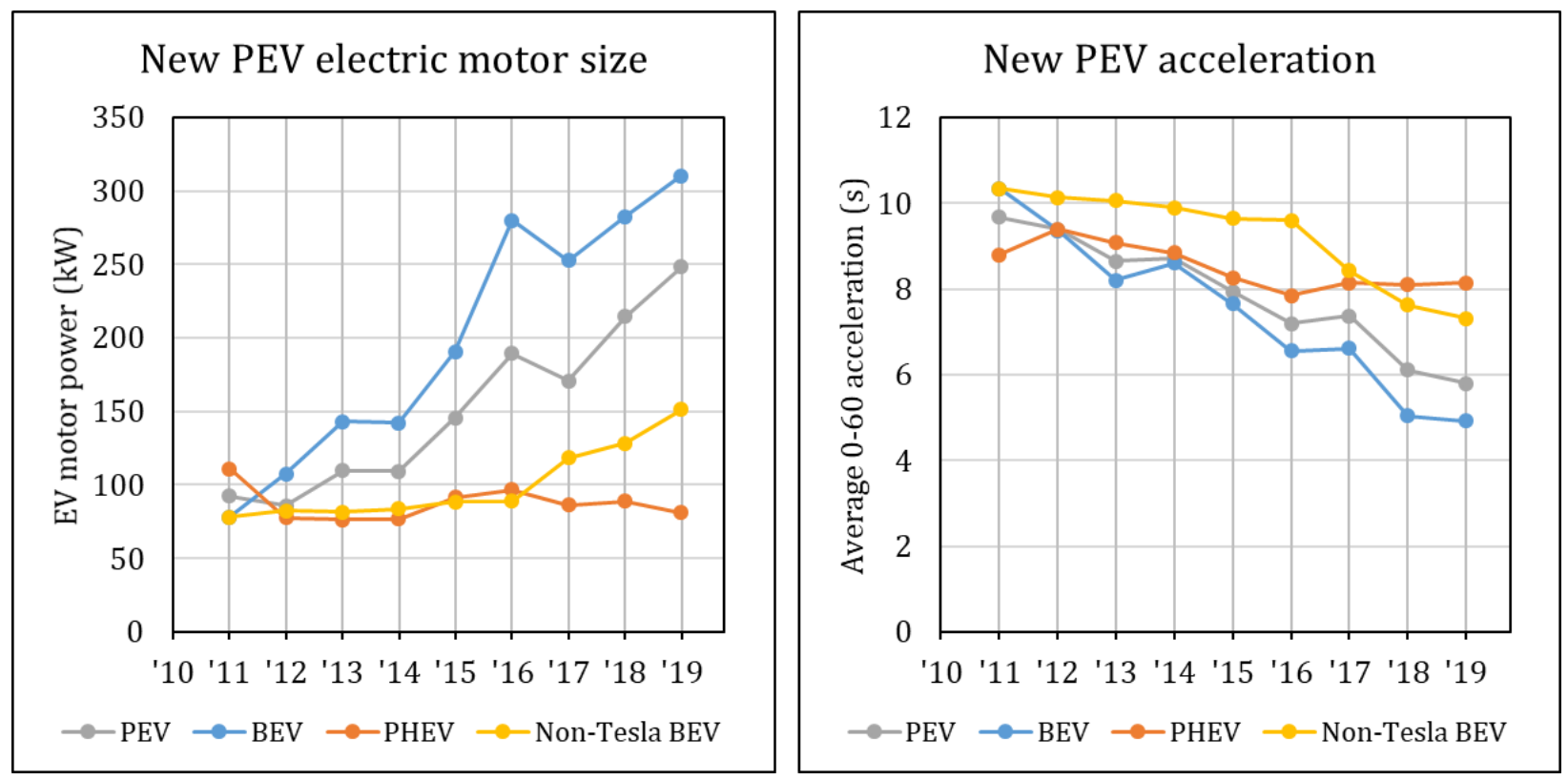

FIGURE 11 Average performance indicators for PEVs sold in each month

As PEV electric motors have become more powerful, vehicle acceleration has improved. The average time for a PEV to reach $60 \mathrm{mph}$ is below 6 seconds. As with the electric motor power, much of the change since 2011 comes from Tesla vehicles. The fastest available PEV is the Tesla Model S P100D, which can reach $60 \mathrm{mph}$ in 2.5 seconds. The average 0-60 mph time for PHEVs has been consistently between 8 and 9 seconds since 2013. Through 2016, the salesweighted average $0-60 \mathrm{mph}$ time for a non-Tesla BEV was 10 seconds, though this has dropped to less than 8 seconds by the end of 2019. This overall improvement in average PEV acceleration rates has multiple causes, including increased availability of models with faster acceleration and some specific models becoming quicker as technology improves.

\footnotetext{
${ }^{10}$ For Tesla vehicles, the characteristics of each model are an estimate of the sales-weighted average across all of the available trims, as Tesla does not separate out the different trim levels in their quarterly sales reports. For lack of nationwide U.S. sales data, the fraction for each trim is estimated based on public registration data from Norway, the United Kingdom, Germany, the Netherlands, and New York State, which combine for about $20 \%$ of the global market (Edvardsen, 2020; GOV.UK, 2019; KBA, 2019; NYS DMV, 2019; RDW, 2019).
} 


\subsection{VEHICLE MANUFACTURING AND ASSEMBLY}

Most electric vehicles that have been sold in the United States were assembled in the United States, as shown in Figure 12. 88\% of BEVs and 43\% of PHEVs have been assembled in the United States. Most of the remaining PEVs sold in the United States were assembled in Japan, Germany, and Mexico. A higher fraction of PEVs have been assembled domestically than ICE vehicles since 2011.

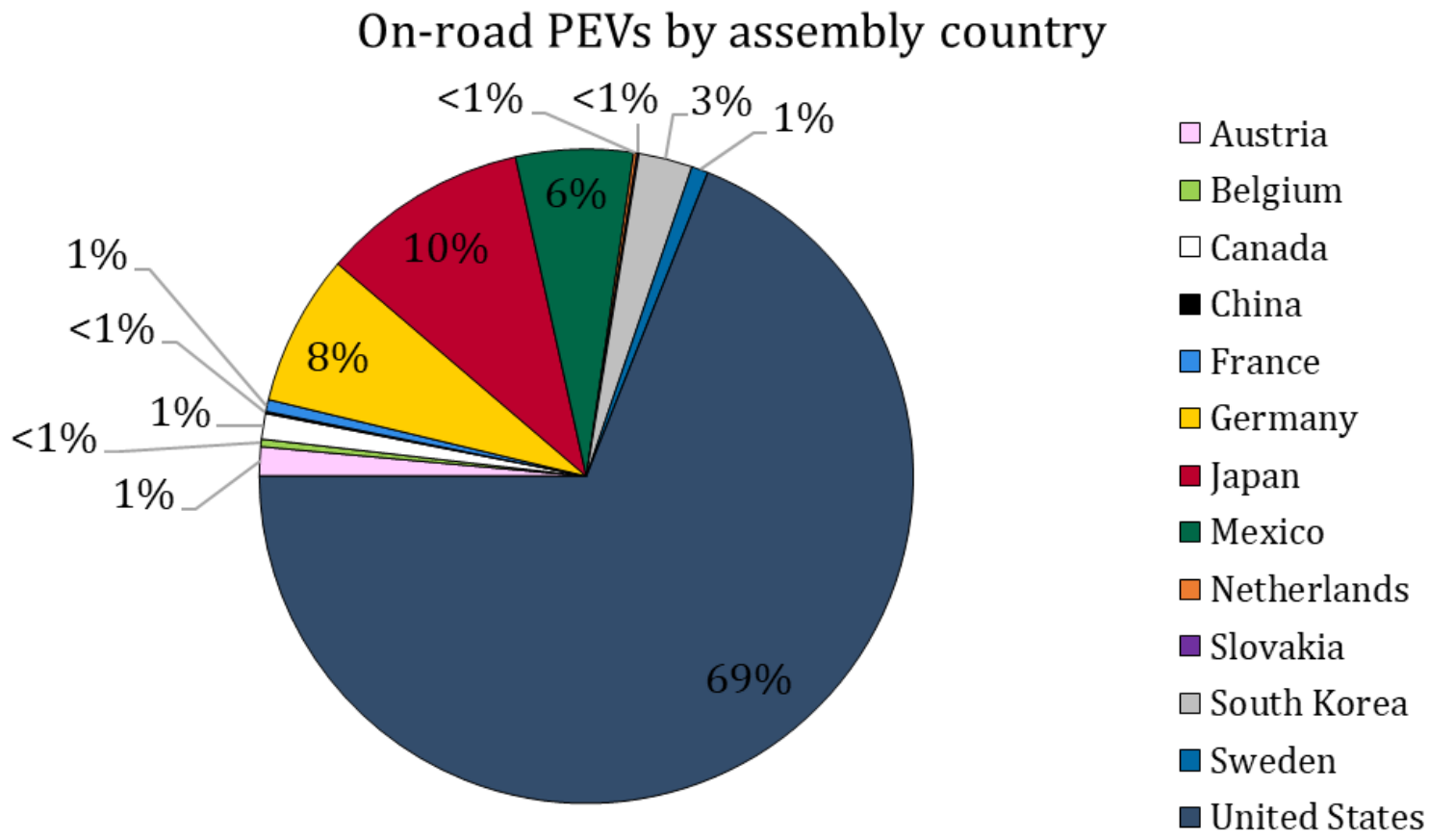

FIGURE 12 Assembly location for PEVs sold in the United States through 2019

Figure 13 shows how assembly location and vehicle content has changed over time. In 2011 and early 2012, most PEVs sold in the United States were assembled in Japan, led by the Nissan Leaf and Toyota Prius Plug-in. By the end of 2012, the Nissan Leaf was being produced in Tennessee and additional models (from Ford and Tesla) were being produced in the United States. From 2013 to 2017, about one-third of PEVs were assembled in foreign countries. In 2018, 74\% of PEV were assembled in the United States, including 96\% of BEV; for comparison, $52 \%$ of non-PEV vehicles were assembled in the United States, based on import data from the Department of Commerce (ITA, 2019). In 2019, largely due to the strong sales of Tesla vehicles, $75 \%$ of PEVs were assembled in the United States. 

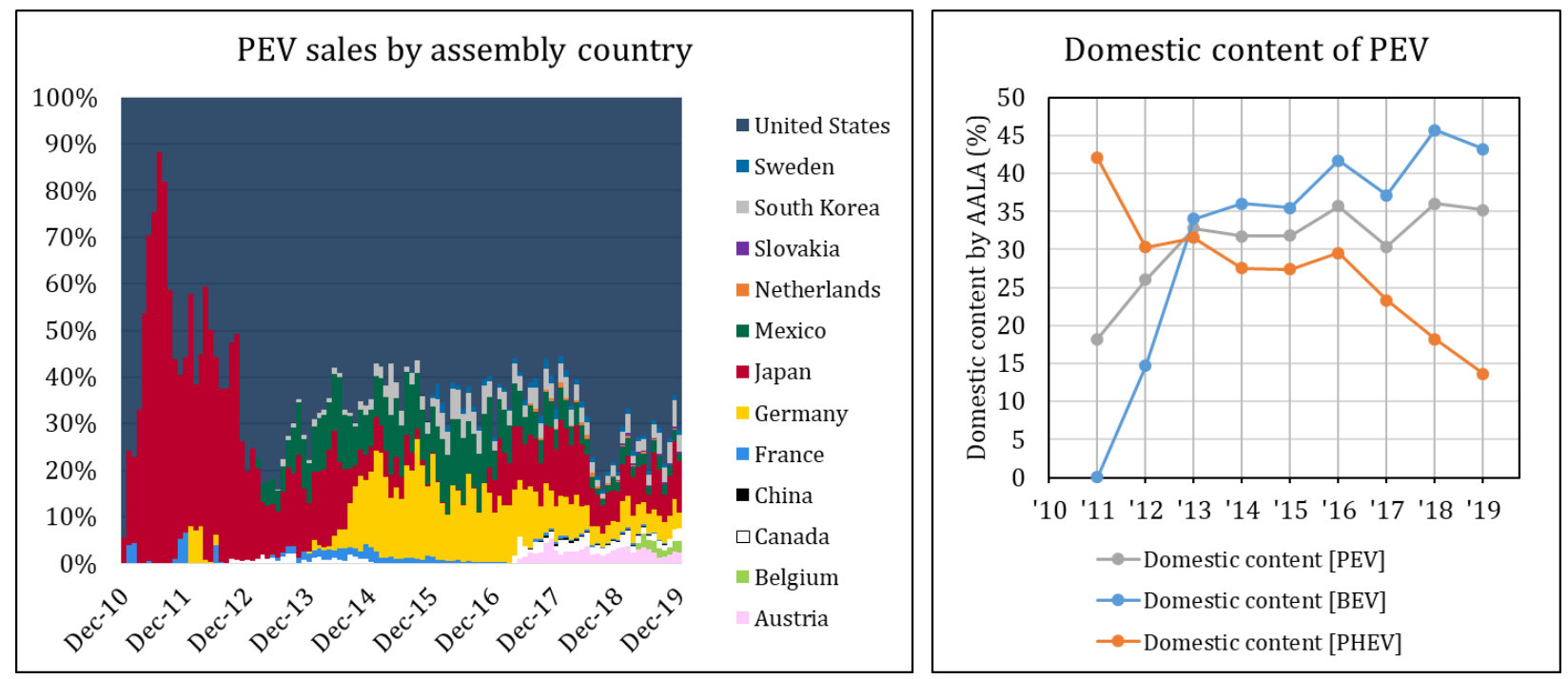

FIGURE 13 Assembly location by month and annual sales-weighted AALA domestic content for PEVs sold in the United States from 2010 to 2019

The fraction of vehicle components that are produced domestically (here defined as both United States and Canada) come from the AALA reports that are compiled by NHTSA for each vehicle model (NHTSA, 2019). Figure 13 shows the sales-weighted average of these AALA values for PEVs sold in the United States. This figure shows that the total amount of domestically sourced materials in electric vehicles has grown since 2011, with strong growth from 2011 to 2013 for BEVs. In 2013, about one-third of components in both BEVs and PHEVs were domestically sourced. ${ }^{11}$ Since then, the fraction of domestic content in PHEVs has declined, largely due to an increasing selection of models produced throughout the world. The fraction of domestic content in BEVs has increased, due to the growth in sales by Tesla and the assembly of Nissan Leafs in the United States.

A similar quantification of U.S. manufacturing is put together by the Kogod School of Business at American University. In their 'Made in America' index they compile their estimate of domestic production which includes investment and different vehicle components (Dubois, 2019). ${ }^{12}$ In the most recent 2019 MIA estimate, the Chevrolet Volt ranked as the most domestically sourced vehicle while the Tesla Model S was \#8.

${ }^{11}$ AALA reports do not account for changes in manufacturing process throughout the year. For example, in early 2013 the Nissan Leaf was largely imported. By the end of the year, the Smyrna plant in Tennessee was assembling Nissan Leafs with a larger fraction of domestically sourced parts, but that does not show up in the AALA report for MY2013 vehicles (Voelker, 2013).

${ }^{12}$ A large portion of the Kogod Made in America Index is informed by NHTSA's AALA estimates, so they are not entirely independent of each other. 


\subsection{VEHICLE PRICE}

Figure 14 shows the sales-weighted average MSRP for PEVs for 2010-2019. ${ }^{13}$ The costs shown here are the base trim MSRP. ${ }^{14}$ This is not necessarily the cost a consumer will pay for the vehicle (and does not include state or federal tax incentives) but is a price that can be referenced as a benchmark for each vehicle. For comparison, the average consumer expenditure for LDVs, as per the Bureau of Economic Analysis, is shown (BEA, 2020). The average cost of BEVs has gone up somewhat since 2010, while the average cost of PHEVs has remained effectively flat since then. The average MSRP for BEVs peaked in 2016 and has declined since then. For individual vehicle models, the prices have largely dropped or stayed steady. However, consumers have opted for more expensive models, increasing the average cost of PEVs.

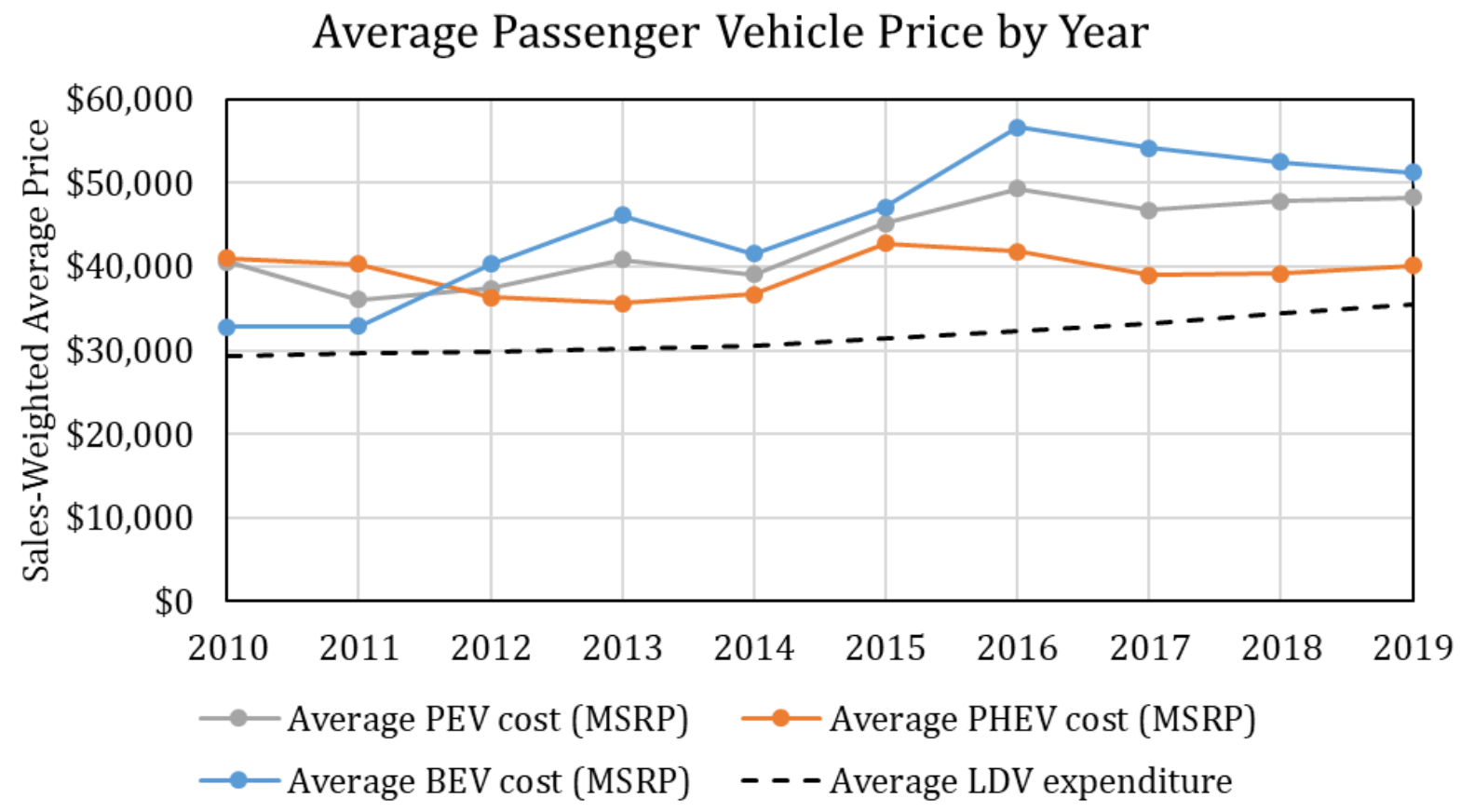

FIGURE 14 Average MSRP for PEV sold from 2010 to 2019; average expenditure for lightduty vehicles from BEA included for comparison

Purchases of PEVs are eligible for a federal tax credit of up to $\$ 7,500$ (IRS, 2009). This tax credit exists until the automaker sells its $200,000^{\text {th }} \mathrm{PEV}$, at which point the credit phases out over the next year. Tesla and General Motors have both reached the threshold for the tax credit to be phased out (IRS, 2018; IRS, 2019), with the tax credit for Tesla vehicles reaching zero in January 2020 and the tax credit for General Motors vehicles reaching zero in April 2020.

${ }^{13}$ All values here are nominal dollars, not inflation-adjusted. From 2011 to 2019, the Consumer Price Index (CPI) increased by $1.6 \%$ per year, and so a cost in 2011 would need to be increased by $14 \%$ to be adjusted for inflation to $2019 \$$.

${ }^{14}$ There are many vehicle models which have a large suite of optional technologies and features which can bring the cost higher than the base level. However, the base trim for many PEVs is often comparable to a higher trim level for ICE vehicles. 


\subsection{BATTERY CAPACITY AND CATHODE CHEMISTRY}

Since 2010, the commercially available PEVs in the United States have used lithium-ion batteries for energy storage. These batteries are comparatively lightweight, and batteries with capacities of up to $100 \mathrm{kWh}$ have been included in PEVs. The core components of lithium-ion batteries are the anode and the cathode. Most lithium-ion batteries have a graphite anode, though a few vehicles (e.g. Mitsubishi i-MiEV, Honda Fit) have used lithium titanate (LTO, $\mathrm{Li}_{4} \mathrm{Ti}_{5} \mathrm{O}_{12}$ ) instead (Blomgren, 2017). The cathode is the most expensive component of the lithium-ion battery (Pillot and Sanders, 2017), and there are numerous competing chemistries for the cathode.

The most common cathode chemistries for lithium ion batteries for automotive uses are $\mathrm{LiNi}_{0.8} \mathrm{Co}_{0.15} \mathrm{Al}_{0.05} \mathrm{O}_{2}$ (NCA), $\mathrm{Li}\left[\mathrm{Ni}_{1-\mathrm{x}-\mathrm{y}} \mathrm{Mn}_{\mathrm{x}} \mathrm{Co}_{\mathrm{y}}\right] \mathrm{O}_{2}$ (NMC), $\mathrm{LiMn}_{2} \mathrm{O}_{4}$ (LMO), and $\mathrm{LiFePO}_{4}$ (LFP). For a detailed description of the relative merits of each of these chemistries, see e.g. Berman et al. (2018), Andre et al. (2015) and Schmuch et al. (2018). These four cathode chemistries are the most common worldwide (EV Volumes, 2017b; Azevedo et al., 2018). As of 2017, NMC and NCA each made up about one-third of the total installed capacity worldwide, and LFP and LMO comprised nearly all of the rest. There are trends toward higher nickel content (and lower cobalt content) in NMC batteries to reduce costs (Berman et al., 2018). ${ }^{15}$ It is generally not reported what stoichiometry battery cathodes use in each PEV, though NMC-111 was the most common for the first mass-market PEVs in 2010, and NMC-622 and NMC-811 are beginning to be produced (Pillot and Sanders, 2017).

Figure 15 shows the primary cathode material for electric vehicles sold in the United States over time. ${ }^{16}$ The left figure is a function of vehicle sales, and the right figure shows the total battery capacity (in MWh) for each cathode chemistry. Figure 15 shows that NMC and NCA are the dominant cathode chemistries in the United States in 2019. Further, while NCA and NMC were used as the battery cathode in a similar number of vehicles, the total capacity was nearly four times higher for NCA, indicating that NCA has been used in much larger packs, on average.

\footnotetext{
15 The stoichiometric ratio of nickel, manganese, and cobalt can be varied in NMC batteries. NMC batteries are often labeled as NMC-xyz, where $\mathrm{x}, \mathrm{y}$, and $\mathrm{z}$ are the ratios between $\mathrm{Ni}, \mathrm{Mn}$, and Co.

${ }^{16}$ It is common for cathode chemistries to be mixed. In particular, LMO and NMC are often mixed in batteries - for ease of representation, the present analysis shows only the primary cathode chemistry.
} 

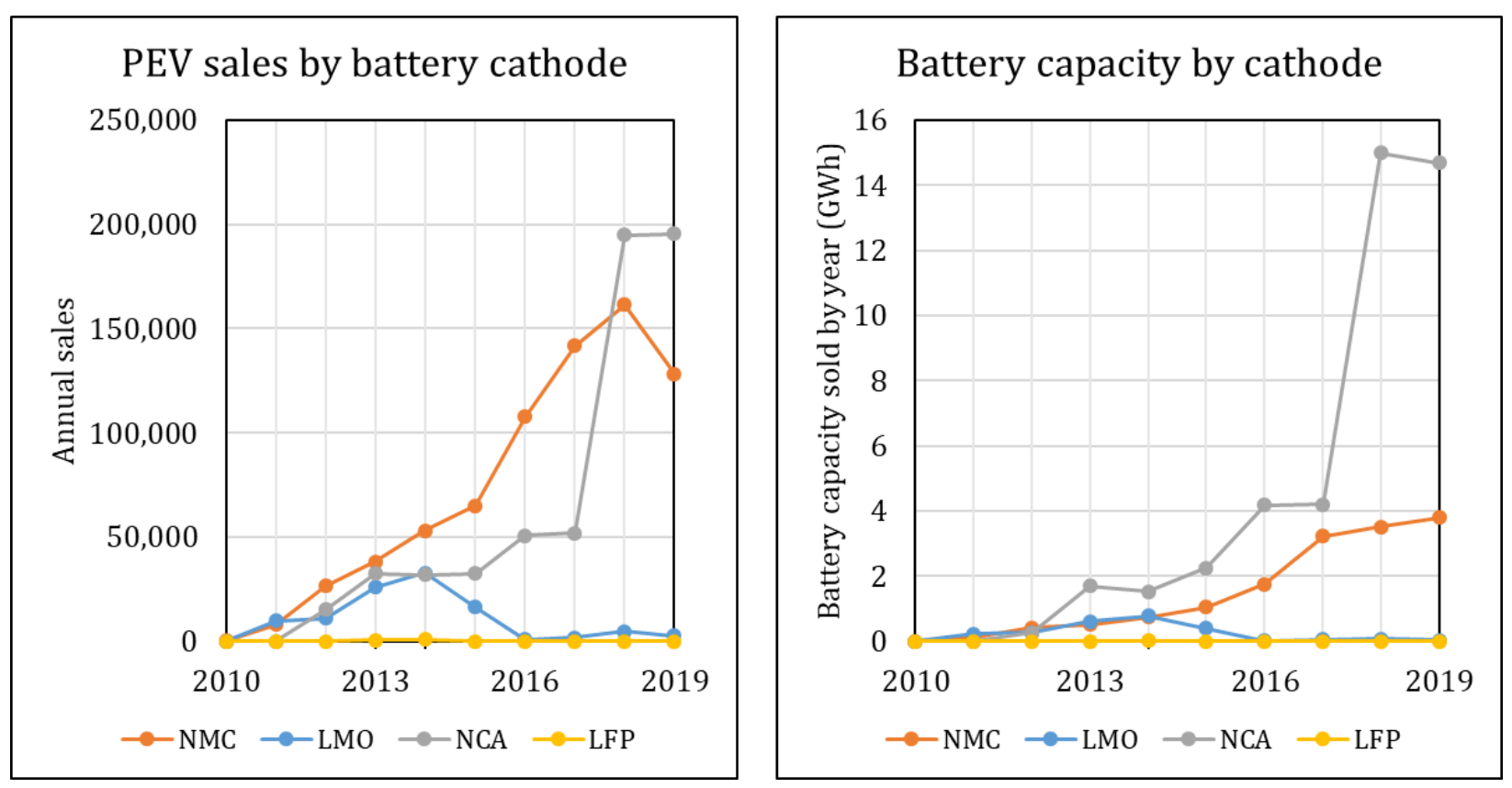

FIGURE 15 Battery capacity added each year for LDV PEVs in the United States

The aggregate battery capacity in PEVs sold in the United States is over 61 gigawatthours (GWh) through 2019. Table 2 and Figure 15 shows the new batteries added to the road each year from 2010 through 2019; new battery capacity was over $18 \mathrm{GWh}$ in 2019. Of this, 14 GWh used NCA cathodes, and nearly 4 GWh used NMC cathodes. 91\% of PHEVs sold in 2019 used lithium-ion batteries with NMC cathodes. More than $70 \%$ of the total battery capacity has used NCA cathodes, and most of these NCA batteries have been installed in Tesla vehicles. Table 2 shows total battery capacity by year for BEV and PHEV. Though BEV comprise only $73 \%$ of the total PEV market, $88 \%$ of all battery capacity has been installed in BEVs in the United States.

TABLE 2 New Lithium-Ion Battery Capacity (GWh) for BEV and PHEV Each Year Since 2010

\begin{tabular}{|c|c|c|c|c|c|c|c|c|c|c|c|}
\hline Year & 2010 & 2011 & 2012 & 2013 & 2014 & 2015 & 2016 & 2017 & 2018 & 2019 & Total \\
\hline $\begin{array}{l}\text { BEV } \\
\text { capacity } \\
\text { (GWh) }\end{array}$ & 0.0 & 0.2 & 0.5 & 2.3 & 2.4 & 3.0 & 5.0 & 6.3 & 16.9 & 17.4 & 54.1 \\
\hline $\begin{array}{l}\text { PHEV } \\
\text { capacity } \\
(\text { GWh) }\end{array}$ & 0.0 & 0.1 & 0.5 & 0.5 & 0.6 & 0.7 & 1.0 & 1.2 & 1.6 & 1.1 & 7.3 \\
\hline $\begin{array}{l}\text { Total PEV } \\
\text { capacity } \\
\text { (GWh) }\end{array}$ & 0.0 & 0.3 & 0.9 & 2.8 & 3.1 & 3.7 & 6.0 & 7.5 & 18.6 & 18.5 & 61.5 \\
\hline
\end{tabular}




\section{SENSITIVITY ANALYSES}

This section explores variations in the input data and assumptions to examine the robustness of the results. This was done in detail in the previous iteration of this report (Gohlke and Zhou, 2018) and many results here reference that work. The largest variations in the results come from assumptions about traveler behavior and ICE vehicle replacement. Impacts from considering scrappage and end-of-life are also described in this section.

\subsection{TRAVELER BEHAVIOR}

The baseline VMT in this study was fixed at 13,500 miles/year. As noted above in Section 2, this corresponds to the average distance driven by a comparable ICE vehicle (Lu, 2006). Tuning this parameter affects all vehicles equally and acts as a simple linear scaling factor for eVMT, electricity consumption, gasoline displacement, and $\mathrm{CO}_{2}$ emissions.

The fraction of PHEV VMT driven on electricity is determined by a utility factor, and BEVs have an effective utility factor in this report, which can be thought of as representing driver reluctance to fully discharge the battery or use BEVs for long-distance trips. These behavioral factors are strongly dependent on the vehicle make and model, and average values are used in this report. The previous iteration of this report (Gohlke and Zhou, 2018) explored these utility factors in depth. In that report, using the SAE Fleet Utility Factor resulted in 6\% lower eVMT, while the utility factors from the World harmonized Light vehicles Test Procedure increased eVMT by up to $16 \%$.

\subsection{VEHICLE SALES AND STOCK}

Default sales estimates in this analysis come from Argonne National Laboratory (ANL, 2020), Wards Auto (Wards, 2019), Inside EVs (Inside EVs, 2020), and HybridCars (Cobb, 2018). In 2019 many automakers stopped reporting monthly sales data for each model, so there are variations between these sales estimates, though the results are similar for all sales estimates considered.

Tesla reports sales quarterly and globally and aggregates across all trim levels for each model. This results in uncertainty for sales estimates and about which vehicles were sold. For example, for MY2016, 13 different trim levels were available for the Model S with battery sizes ranges from $60 \mathrm{kWh}$ to $100 \mathrm{kWh}$, efficiencies ranging from $0.32 \mathrm{kWh} / \mathrm{mile}$ to $0.38 \mathrm{kWh} / \mathrm{mile}$, and all-electric ranges from 210 miles to 315 miles. In this report, the baseline weighting factors of sales of each trim level for each model are derived from public registration data from Norway, the United Kingdom, Germany, the Netherlands, and New York State (Edvardsen, 2019; GOV.UK, 2019; KBA, 2019; NYS DMV, 2019; RDW, 2019). Generation of these weighting factors will be described in a future report (Gohlke, 2020 forthcoming). Because the effective utility factor for the Tesla vehicles is high for every model, the impact of the exact variation in vehicle attributes is small for the macroeconomic aggregated indicators (i.e., VMT, electricity consumption, gasoline displacement, and carbon emissions). For example, for MY2016 Tesla 
Model S, the longest driving range is $50 \%$ greater than the lowest driving range, but its effective utility factor is only 5\% higher (as described in Figure 3). Uncertainty in the vehicle mix does have a major impact on battery capacity and performance measures. Cumulative battery production ranges between 50.2 GWh and 64.8 GWh through December 2019 depending on if all Tesla vehicles have the smallest or largest batteries available, respectively. Since 2015, each Tesla model has offered a performance version, which has acceleration that can be more than twice as quick as the base version (e.g., 0-60 mph times ranging from $2.5-5.5$ seconds for the 2017 Model S).

Scrappage effects are currently small. Using National Highway Traffic Safety Administration's (NHTSA) 2006 report as the basis of scrappage rates, which uses historic data from ICE vehicles (Lu, 2006), 3.3\% of PEVs sold have been taken off the road, as of December 2019. ${ }^{17}$ This fraction is small because of the average age of PEVs. The average age of on-road PEVs is only 33 months, due to their recent introduction into the market and the rapid growth in sales. If PEV sales remain steady at 2019 levels (30,000 sales per month), scrappage will not reach $10 \%$ until after 2025 , and the overall fraction of scrapped vehicles will be lower still if PEV sales increase (due to a younger average PEV fleet).

A potentially larger impact comes from reduction of vehicle use as the vehicle ages. NHTSA has a vehicle mileage schedule for estimated travel by age of vehicle, based on historical ICE data (Lu, 2006). Translating this vehicle mileage schedule (for cars) to the PEV sales since 2010 yields a 4\% reduction in VMT from 2010 through 2019. It is unknown if this methodology translates to eVMT driven by PEVs. ${ }^{18}$ Using data from the 2017 National Household Travel Survey (NHTS), BEVs exhibit no clear reduction in mileage for vehicles dating back to 2011, while PHEVs show a decrease in mileage using NHTS's best estimate, but an increase in mileage when relying on self-reported mileage. In either case, the sample size for each of these vehicles is small.

Due to the effects of scrappage and vehicle travel effects, the impacts of PEV usage on gasoline displacement and electricity use may be overestimated. Combining the reduction in onroad vehicles with the reduction in mileage for older vehicles (both assuming equivalent reductions as ICE vehicles), the cumulative gasoline displacement and electricity use are potentially up to $6.2 \%$ lower through December 2019.

\footnotetext{
${ }^{17}$ For the first several years of a vehicle's life, the scrappage rate from NHTSA is approximately $0.12 \%$ per month. The EPA Technical Assessment Report (EPA, 2016) assumes an even slower scrappage rate.

18 There are logical reasons that the eVMT could either be reduced or stay the same. For BEVs, a reduction in VMT is identical to a reduction in eVMT though travel behavior for BEV is not the same as ICE vehicles. For PHEVs, only a fraction of the miles are electrified; in particular, the first miles of most trips. If long-range travel is reduced as the vehicle ages, this does not impact the eVMT and instead raises the effective utility factor. If, conversely, fewer trips are taken, but at a proportionally longer distance, this would lower eVMT. Additionally, battery degradation can cause the all-electric range of PEVs to decrease as the vehicle ages, which would lower the potential eVMT.
} 
Because all-electric range has increased since 2010, the impact of scrappage on battery capacity is smaller than for the entire vehicle. As of December 2019, only $2.5 \%$ of lithium-ion batteries in PEVs (approximately 1.6 gigawatt-hours) will have been scrapped based on historic trends.

\subsection{COMPARABLE ICE VEHICLES}

As described in Section 2.4, the reduction in gasoline attributed to PEVs depends on the ICE vehicle that each PEV is assumed to replace. The baseline assumption in this report is that each PEV offsets the $75^{\text {th }}$ percentile vehicle in its size class, however different comparison ICE vehicles can be compared instead. Table 3 shows the impact of changing the comparable vehicle. The total eVMT and electricity consumption do not vary, but the gallons of gasoline offset through 2019 ranges from 950 million to 1.7 billion gallons and cumulative $\mathrm{CO}_{2}$ reductions range from 2.8 to 9.6 million metric tons. The lower bound comes from all PEVs replacing an ICE vehicle consuming 40 miles per gallon, while the upper bound scenario has all PEVs replace the average on-road ICE vehicle in its size class.

In Table 3, the first row represents PEVs replacing a gasoline-fueled ICE vehicle equivalent in fuel economy to the $75^{\text {th }}$ percentile vehicle in that size class for that year. The second row takes the harmonic mean of fuel economy for all vehicles in the size class for each year and uses that as the displaced vehicle. The next three rows treat all PEVs the same, regardless of size class, as if they are replacing an average ICE vehicle with fuel economy equivalent to the average vehicle sale in that year, $30 \mathrm{mpg}$, or $40 \mathrm{mpg}$, respectively. In the final row, rather than displace the purchase of a new ICE vehicle, the PEVs are displacing an average vehicle already in use when the PEV is sold.

TABLE 3 Comparison of Total Gasoline Reduction and $\mathrm{CO}_{2}$ Emissions Reduction with Different ICE Vehicles for Comparison

\begin{tabular}{|lcc|}
\hline \multicolumn{1}{|c|}{ Replaced ICE vehicle } & $\begin{array}{c}\text { Gasoline reduction } \\
\text { (million gallons) }\end{array}$ & $\begin{array}{c}\mathrm{CO}_{2} \text { emissions reduction } \\
\text { (million metric tons) }\end{array}$ \\
\hline $75^{\text {th }}$ percentile by size class [baseline] & 1,410 & 6.93 \\
Average by size class & $1,640(+16.1 \%)$ & $8.95(+29.1 \%)$ \\
Fleet average new LDV (EPA, 2019b) & $1,540(+9.4 \%)$ & $8.11(+17.0 \%)$ \\
30 miles per gallon & $1,260(-10.5 \%)$ & $5.62(-19.0 \%)$ \\
40 miles per gallon & $946(-32.9 \%)$ & $2.81(-59.4 \%)$ \\
Average on-road LDV & $1,710(+21.1 \%)$ & $9.58(+38.1 \%)$ \\
\hline
\end{tabular}




\section{CONCLUSIONS}

Since the latest generation of light-duty plug-in electric vehicles have been available in the United States, more than 1.4 million PEVs have been sold, driving nearly 38 billion miles on electricity. These 38 billion eVMT consumed more than 12.5 terawatt-hours of electricity while reducing gasoline consumption nationwide by 1.4 billion gallons. Table 4 reproduces Table 1 , summarizing the total impacts of PEVs by year from 2011 to 2019. Mileage driven by PEVs and electricity consumption has grown, which has offset gasoline consumption and $\mathrm{CO}_{2}$ emissions from ICE vehicles.

TABLE 4 Annual Sales of New PEVs, and Total Annual eVMT, Gasoline Reduction, Electricity Consumption, and $\mathrm{CO}_{2}$ Emissions Reduction by On-Road PEVs (Duplication of Table 1)

\begin{tabular}{|cccccc|}
\hline Year & $\begin{array}{c}\text { PEV sales } \\
\text { (thousands) }\end{array}$ & $\begin{array}{c}\text { eVMT } \\
\text { (billion miles) }\end{array}$ & $\begin{array}{c}\text { Gasoline reduction } \\
\text { (million gallons) }\end{array}$ & $\begin{array}{c}\text { Electricity } \\
\text { consumption } \\
\text { (gigawatt-hours) }\end{array}$ & $\begin{array}{c}\mathrm{CO}_{2} \text { emissions } \\
\text { reduction } \\
\text { (million metric tons) }\end{array}$ \\
\hline & & & & & \\
2011 & 18 & 0.1 & 2 & 20 & 0.01 \\
2012 & 53 & 0.3 & 12 & 110 & 0.05 \\
2013 & 97 & 1.0 & 37 & 330 & 0.17 \\
2014 & 119 & 1.9 & 72 & 650 & 0.33 \\
2015 & 114 & 3.0 & 110 & 1,000 & 0.53 \\
2016 & 160 & 4.3 & 160 & 1,400 & 0.77 \\
2017 & 196 & 6.0 & 230 & 2,000 & 1.10 \\
2018 & 361 & 8.6 & 320 & 2,800 & 1.60 \\
\hline 2019 & 327 & 12.7 & 470 & 4,100 & 2.40 \\
\hline Total & $\mathbf{1 , 4 5 0}$ & $\mathbf{3 7 . 9}$ & $\mathbf{1 , 4 1 0}$ & $\mathbf{1 2 , 5 0 0}$ & $\mathbf{6 . 9 0}$ \\
\hline
\end{tabular}

On average, electric vehicles have become more fuel efficient and have had longer allelectric driving ranges as technology has advanced. This improvement in efficiency has occurred even while performance metrics (such as vehicle power or acceleration) have improved as well. Most of the PEVs on the road were assembled in the United States. The market has begun to grow beyond the midsize and compact cars which were most common, with plug-in electric SUVs becoming more popular as models become available.

Some of the results shown in Table 3 depend on assumptions on traveler and purchase behavior. A previous report (Gohlke and Zhou, 2018) showed that different assumptions about driving behavior can change eVMT and electricity consumption by up to $25 \%$. Using alternative choices for the ICE vehicle travel displaced by a PEV yields anywhere between 950 million and 1.7 billion gallons of gasoline displaced.

More than two-thirds of PEVs have been assembled in the United States, and more than one-third of the total content is domestically sourced. Over $60 \mathrm{GWh}$ of battery capacity has been installed in PEVs since 2010, and more than 30\% of this total was in 2019. 


\section{REFERENCES}

Andre, Dave, Sung-Jim Kim, Peter Lamp, Simon Franz Lux, Filippo Maglia, Odysseas Paschos, and Barbara Stiaszny, 2015. Future generations of cathode materials: an automotive industry perspective. J. Mater. Chem. A. 3, 6709-6732. doi: 10.1039/c5ta00361j https://pubs.rsc.org/en/Content/ArticleLanding/2015/TA/C5TA00361J

ANL (Argonne National Laboratory), 2020. Light Duty Electric Drive Vehicles Monthly Sales Update. Accessed February 5, 2020. https://www.anl.gov/es/light-duty-electric-drive-vehicles$\underline{\text { monthly-sales-updates }}$

Azevedo, Marcelo, Nicolò Campagnol, Toralf Hagenbruch, Ken Hoffman, Ajay Lala, Oliver Ramsbottom, 2018. "Lithium and cobalt - a tale of two commodities." Metals and Mining, June 2018. https://www.mckinsey.com/ /media/mckinsey/industries/ metals\%20and\%20mining/our\%20insights/lithium\%20and\%20cobalt \%20a\%20tale \%20of\%20 two\%20commodities/lithium-and-cobalt-a-tale-of-two-commodities.ashx

BEA (Bureau of Economic Analysis), 2020. National Income and Product Accounts. Revised January 31, 2020. https://apps.bea.gov/iTable/iTable.cfm?reqid=19\&step=2

Berman, Kimberly, Jared Dziuba, Colin Hamilton, Richard Carlson, Joel Jackson, and Peter Sklar, 2018. "The Lithium Ion Battery and the EV Market: The Science Behind What You Can't See." BMO Capital Markets, February 2018. https://bmo.bluematrix.com/docs/pdf/079c275e-3540-4826-b143-84741aa3ebf9.pdf

Blomgren, George E., 2017. The Development and Future of Lithium Ion Batteries. Journal of the Electrochemical Society. 164(1), A5019-A5025. doi: 10.1149/2.0251701jes

http://jes.ecsdl.org/content/164/1/A5019

CARB (California Air Resources Board), 2017a. California's Advanced Clean Cars Midterm Review, Appendix G: Plug-in Electric Vehicle In-Use and Charging Data Analysis. January 18, 2017. https://www.arb.ca.gov/msprog/acc/mtr/appendix_g.pdf

CARB (California Air Resources Board), 2017b. California's Advanced Clean Cars Midterm Review, Appendix I: Alternative Credits for Zero Emission Vehicles and Plug-in Hybrid Electric Vehicles. January 18, 2017. https://www.arb.ca.gov/msprog/acc/mtr/appendix_i.pdf

Carlson, Barney, 2015. Electric Vehicle Mile Traveled (eVMT): On-road Results and Analysis. Report INL/MIS-15-34807. http://energy.gov/sites/prod/files/2015/07/f24/vss171_carlson_2015_p.pdf

Cobb, Jeff, 2018. “December 2017 Dashboard.” HybridCars, January 4, 2018. http://www.hybridcars.com/december-2017-dashboard/ 
DOE (U.S. Department of Energy), 2017. Motor Gasoline Is Most Common Petroleum Product from U.S. Refineries. February 13, 2017. https://energy.gov/eere/vehicles/fact-964february-13-2017-motor-gasoline-most-common-petroleum-product-us-refineries

DOE (U.S. Department of Energy), 2018. One Million Plug-in Vehicles Have Been Sold in the United States. November 26, 2018. https://www.energy.gov/eere/vehicles/articles/fotw-1057november-26-2018-one-million-plug-vehicles-have-been-sold-united

DOE (U.S. Department of Energy), 2019. Batteries: 2018 Annual Progress Report. Report DOE/EE-1831. April 2019. https://www.energy.gov/eere/vehicles/downloads/batteriesfy2018-annual-progress-report-0

DOE (U.S. Department of Energy), 2020. U.S. Light-Duty Vehicle Sales in 2019 Were Nearly 17 Million Vehicles. January 13, 2020. https://www.energy.gov/eere/vehicles/articles/fotw1116-january-13-2020-us-light-duty-vehicle-sales-2019-were-nearly-17

DOE and EPA (U.S. Department of Energy and Environmental Protection Agency), 2020. FuelEconomy.gov. Accessed February 5, 2020. http://fueleconomy.gov/

Dubois, Frank, 2019. Kogod School of Business Made in America Auto Index. Accessed December 18, 2019. https://www.american.edu/kogod/research/autoindex/index.cfm

Duoba, Michael, 2013. Developing a Utility Factor for Battery Electric Vehicles. SAE International Journal of Alternative Powertrains. 2(2), 362-368. doi:10.4271/2013-01-1474 https://saemobilus.sae.org/content/2013-01-1474/

Edvardsen, Lasse, 2020. General Tesla Registration Stats. Accessed February 3, 2020. https://teslastats.no/

EEI (Edison Electric Institute), 2018. Plug-in Electric Vehicle Sales Forecast Through 2025 and the Charging Infrastructure Required Through 2030. Prepared by Adam Cooper and Kellen Schefter, November 2018. https://www.edisonfoundation.net/iei/publications/Documents/IEI_EEI\%20EV\%20Forecast\% 20Report_Nov2018.pdf

EIA (Energy Information Administration), 2019. Monthly Energy Review. Accessed December 20, 2019. https://www.eia.gov/totalenergy/data/monthly/

Elgowainy, Amgad, Jeongwoo Han, Jacob Ward, Fred Joseck, David Gohlke, Alicia Lindauer, Todd Ramsden, Mary Biddy, Marcus Alexander, Steven Barnhart, Ian Sutherland, Laura Verduzco, Timothy J. Wallington, 2016. Cradle-to-Grave Lifecycle Analysis of U.S. LightDuty Vehicle-Fuel Pathways: A Greenhouse Gas Emissions and Economic Assessment of Current (2015) and Future (2025-2030) Technologies. Report ANL/ESD-16/7. https://greet.es.anl.gov/publication-c2g-2016-report 
EPA and DOT (U.S. Environmental Protection Agency and Department of Transportation), 2010. Light-Duty Vehicle Greenhouse Gas Emission Standards and Corporate Average Fuel Economy Standards; Final Rule. Federal Register, Vol. 75, no. 88, pg. 25324. May 7, 2010. https://www.gpo.gov/fdsys/pkg/FR-2010-05-07/pdf/2010-8159.pdf

EPA (U.S. Environmental Protection Agency), 2011. New Fuel Economy and Environment Labels for a New Generation of Vehicles. Report EPA-420-F-11-017. https://nepis.epa.gov/Exe/ZyPURL.cgi?Dockey=P100BAV0.TXT

EPA (U.S. Environmental Protection Agency), 2016. Midterm Evaluation of Light-Duty Vehicle Greenhouse Gas Emission Standards and Corporate Average Fuel Economy Standards for Model Years 2022-2025. July, 2016. https://nepis.epa.gov/Exe/ZyPDF.cgi/P100OXEO.PDF?Dockey=P100OXEO.PDF

EPA (U.S. Environmental Protection Agency), 2019a. Data on Cars used for Testing Fuel Economy. December 12, 2019. https://www.epa.gov/compliance-and-fuel-economy-data/datacars-used-testing-fuel-economy

EPA (U.S. Environmental Protection Agency), 2019b. The 2018 EPA Automotive Trends Report: Greenhouse Gas Emissions, Fuel Economy, and Technology since 1975. Report EPA420-R-19-002. https://www.epa.gov/automotive-trends/download-automotive-trends-report

EPA (U.S. Environmental Protection Agency), 2020. Emissions \& Generation Resource Integrated Database (eGRID): eGRID2018. January 28, 2020.

https://www.epa.gov/energy/emissions-generation-resource-integrated-database-egrid

EV Volumes, 2017a. China Plug-in Volumes for Q3-2017 and October-November. Accessed June 8, 2018. http://www.ev-volumes.com/news/china-plug-in-volumes-for-q3-2017-october/

EV Volumes, 2017b. Global Plug-in Vehicle Sales for 2017 H1 + July, August Update. Accessed December 5, 2018. http://www.ev-volumes.com/news/global-plug-in-vehicle-salesfor-2017-h1-july-august-update/

Figenbaum, Erik and Marika Kolbenstvedt, 2016. Learning from Norwegian Battery Electric and Plug-in Hybrid Vehicle users - Results from a survey of vehicle owners. Report TØI 1492/2016. Institute of Transport Economics: Oslo, Norway. ISBN 978-82-480-1789-9. https://www.toi.no/publications/learning-from-norwegian-battery-electric-and-plug-in-hybridvehicle-users-results-from-a-survey-of-vehicle-owners-article33869-29.html

FHWA (Federal Highway Administration), 2019a. Highway Statistics 2017: State MotorVehicle Registrations - 2017. January 2019. https://www.fhwa.dot.gov/policyinformation/statistics/2017/mv1.cfm

FHWA (Federal Highway Administration), 2019b. Highway Statistics 2018: Annual Vehicle Distance Traveled in Miles and Related Data - 2018. March 2019. https://www.fhwa.dot.gov/policyinformation/statistics/2018/vm1.cfm 
Gohlke, David and Joann Zhou, 2018. Impacts of Electrification of Light-Duty Vehicles in the United States, 2010 - 2017. Report ANL/ESD-18/1. http://dx.doi.org/10.2172/1418278

Gohlke, David and Joann Zhou, 2019. Assessment of Light-Duty Plug-in Electric Vehicles in the United States, 2010-2018. Report ANL/ESD-19/2. http://dx.doi.org/10.2172/1506474

GOV.UK, 2019. Data on all licensed and registered vehicles, produced by Department for Transport. Accessed January 22, 2019. https://www.gov.uk/government/statistical-data$\underline{\text { sets/all-vehicles-veh01 }}$

Inside EVs, 2019. Monthly Plug-In Sales Scorecard. Accessed January 22, 2019. http://insideevs.com/monthly-plug-in-sales-scorecard/

Irle, Roland, 2018. Europe Plug-in Vehicle Sales for Q3 of 2018. Accessed December 3, 2018. http://www.ev-volumes.com/news/europe-plug-in-vehicle-sales-for-q3-of-2018/

IRS (Internal Revenue Service), 2009. Internal Revenue Bulletin: 2009-48. November 30, 2009. https://www.irs.gov/irb/2009-48_IRB

IRS (Internal Revenue Service), 2018. First plug-in electric vehicle manufacturer crosses 200,000 sold threshold; Tax credit for eligible consumers begins phase down on Jan. 1. IR2018-252. December 14, 2018. https://www.irs.gov/newsroom/first-plug-in-electric-vehiclemanufacturer-crosses-200000-sold-thresholdtax-credit-for-eligible-consumers-begins-phasedown-on-jan-1

IRS (Internal Revenue Service), 2019. Plug-in electric vehicle manufacturer crosses 200,000 sold threshold; tax credit for eligible consumers begins phase down on April 1. IR-2019-57. March 26, 2019. https://www.irs.gov/newsroom/plug-in-electric-vehicle-manufacturer-crosses200000-sold-threshold-tax-credit-for-eligible-consumers-begins-phase-down-on-april-1

ITA (International Trade Administration), 2019. U.S. Imports of New Passenger Vehicles and Light Trucks, value and units. Accessed December 20, 2018.

https://www.trade.gov/td/otm/autostats.asp

Kane, Mark, 2019. "Compare EVs: Guide to Range, Specs, Pricing \& More.” Inside EVs, July 22, 2019. https://insideevs.com/reviews/344001/compare-evs/

KBA (Kraftfahrt-Bundesamt), 2019. Bestand am 1. Januar 2018 nach Marken, Herstellern. Accessed January 22, 2019.

https://www.kba.de/DE/Statistik/Fahrzeuge/Bestand/MarkenHersteller/marken_hersteller_nod e.html

Lu, S., 2006. Vehicle Survivability and Travel Mileage Schedules. Report DOT HS 809952. https://crashstats.nhtsa.dot.gov/Api/Public/ViewPublication/809952 
Mays, Kelsey, 2018. "Cars.com 2018 American-Made Index: What's the Most American Car?" Cars.com, June 21, 2018. https://www.cars.com/articles/carscom-2018-american-made-indexwhats-the-most-american-car-1420700348632/

McGuckin, N. and A. Fucci, 2018. Summary of Travel Trends: 2017 National Household Travel Survey. Report FHWA-PL-18-019.

https://nhts.ornl.gov/assets/2017_nhts_summary travel_trends.pdf

NHTSA (National Highway Traffic Safety Administration), 2019. Part 583 American Automobile Labeling Act Reports. Updated June 4, 2019. https://www.nhtsa.gov/part-583american-automobile-labeling-act-reports

NHTSA and EPA (National Highway Traffic Safety Administration and U.S. Environmental Protection Agency), 2018. The Safer Affordable Fuel-Efficient (SAFE) Vehicles Rule for Model Year 2021 - 2026 Passenger Cars and Light Trucks, Preliminary Regulatory Impact Analysis, updated October 16, 2018. https://www.nhtsa.gov/corporate-average-fueleconomy/safe

Nicholas, Michael A., Gil Tal, and Thomas S. Turrentine, 2017. Advanced Plug-in Electric Vehicle Travel and Charging Behavior Interim Report. Report UCD-ITS-RR-16-10. https://itspubs.ucdavis.edu/index.php/research/publications/publication-detail/?pub_id=2692

NYS DMV (New York State, Department of Motor Vehicles), 2019. Vehicle, Snowmobile, and Boat Registrations. Accessed January 22, 2019. https://data.ny.gov/Transportation/VehicleSnowmobile-and-Boat-Registrations/w4pv-hbkt

OPEC (Organization of the Petroleum Exporting Countries), 2018. 2018 OPEC World Oil Outlook 2040. ISBN 978-3-9503936-6-8. September 2018. https://woo.opec.org/

Pillot, Christophe and Mike Sanders, 2017. Lithium-Ion Battery Raw Material Supply and Demand, 2016 - 2025. Presented at $17^{\text {th }}$ Annual Advanced Automotive Battery Conference, June 19, 2017. http://www.avicenne.com/pdf/LithiumIon\%20Battery\%20Raw\%20Material\%20Supply\%20and\%20Demand\%2020162025\%20C.\%20Pillot\%20-\%20M.\%20Sanders\%20Presentation\%20at\%20AABCUS\%20San\%20Francisco\%20June\%202017.pdf

Plötz, P., S. A. Funke, P. Jochem \& M. Wietschel, 2017. $\mathrm{CO}_{2}$ Mitigation Potential of Plug-in Hybrid Electric Vehicles larger than expected. Scientific Reports 7, 16493:2017. https://www.nature.com/articles/s41598-017-16684-9

Pontes, José, 2020. Global Top 20 - December 2019. January 31, 2020. http://evsales.blogspot.com/2020/01/global-top-20-december-2019.html

RDW (Rijksdienst voor het Wegverkeer), 2019. Open Data RDW: Gekentekende_voertuigen. Accessed January 22, 2019. https://opendata.rdw.nl/en/Voertuigen/Open-Data-RDWGekentekende_voertuigen/m9d7-ebf2/data 
SAE (Society of Automotive Engineers), 2010. Utility Factor Definitions for Plug-In Hybrid Electric Vehicles Using Travel Survey Data. Standard J2841_201009.

http://standards.sae.org/j2841_201009/

Santos, Adella, Nancy McGuckin, Hikari Yukiko Nakamoto, Danielle Gray, and Susan Liss, 2011. Summary of Travel Trends: 2009 National Household Travel Survey. Report FHWAPL-11-022. http://nhts.ornl.gov/2009/pub/stt.pdf

Schmuch, Richard, Ralf Wagner, Gerhard Hörpel, Tobias Placke, and Martin Winter, 2018. Performance and cost of materials for lithium-based rechargeable automotive batteries. Nature Energy. 3, 267-278. doi: 10.1038/s41560-018-0107-2 https://doi.org/10.1038/s41560$\underline{018-0107-2}$

SEPA (Smart Electric Power Alliance), 2017. Utilities and Electric Vehicles: The Case for Managed Charging. https://sepapower.org/resource/ev-managed-charging/

Smart, John Galloway and Shawn Douglas Salisbury, 2015. Plugged in: How Americans Charge Their Electric Vehicles. Report INL/EXT-15-35584.

https://avt.inl.gov/sites/default/files/pdf/arra/PluggedInSummaryReport.pdf

Szinai, Julia K., Colin J.R. Sheppard, Nikit Abhyankar, and Anand R. Gopal, 2020. Reduced grid operating costs and renewable energy curtailment with electric vehicle charge management. Energy Policy. 136, 111051. doi: 10.1016/j.enpol.2019.111051 https://www.sciencedirect.com/science/article/pii/S030142151930638X

Voelcker, John, 2013. "U.S.-Made 2013 Nissan Leaf Has Only 15 Percent Local Content; Here's Why." Green Car Reports, September 30, 2013. https://www.greencarreports.com/ news/1087122_u-s--made-2013-nissan-leaf-has-only-15-percent-local-content-heres-why

Wards Auto, 2019. "WardsAuto." Accessed December 11, 2019. https://www.wardsauto.com 



\section{Argonne}

\section{Energy Systems Division}

Argonne National Laboratory

9700 South Cass Avenue, Bldg. 362

Lemont, IL 60439-4832

www.anl.gov 